\title{
Uncertainty and Risk Analysis of Pakistan's Regional Trade: Fan Chart Approach
}

\author{
Syed Tehseen Jawaid * $\quad$ Abdul Waheed ${ }^{\dagger}$
}

\begin{abstract}
Economic forecasting, both specific and general, is a crucial part of economic planning for a country. It is required to effectively deal with uncertainity as well as possible negative impact of proposed policies in future. Therefore, correct predictions will improve the effectiveness of the decision-making process. This study is a pioneering attempt to forecast aggregate and regional trade of Pakistan by using annual time series data from 1974 to 2014. With the help of fan chart, aggregate and regional trade of Pakistan have been forecast from 2015 to 2020. Fan chart provides ranges of forecast at different levels of significance as well as assesses. The risk associated with the forecast value, namely upside and downside risk. The results suggest that there is considerable uncertainty associated with the regional trade of Pakistan. The policy makers are suggested to monitor downside risk associated with the exports and upside risk associated with the imports of the country.
\end{abstract}

Keywords: Forecasting, Trade, Fan Chart, Risk, Pakistan.

\section{Introduction}

Economic integration is conducive for enhancing growth and development in the developing countries. It also offers important advantages including lower risk associated with investment, lower transaction cost of business, market's expansion, pooling of regional resources, economies of scale and efficient allocation of resources. Still, it is unquestionable that most favorable economic policies are required to achieve these advantages. Additionally, regional trade also elevate number of other than economic issues like regional security and political contacts amid regional countries (Carbaugh, 2004; Raza \& Karim, 2017). Like many other developing countries, Pakistan is actively pursuing the policy of enhancing regional economic cooperation.

Statistics show that Pakistan's trade agreements have significantly impacted its trade which has witnessed a substantial increase over time. With the help of these trade relationships, economic development can be further enhanced in the country. For better economic performance of the country, there is need to forecast aggregate and regional trade to make policies that enhance growth and sustain development in the country in future. A number of studies link trades with other aspects of Pakistan's economy (Jawaid, 2014; Shahbaz, 2012; Hye, 2012; Gul \& Yasin, 2011; Muhammad, 2010; Zaman, 2010; Ullah, Zaman, Farooq, \& Javid, 2009; Din, Ghani, \& Siddique, 2003). Some studies forecast trade volume at aggregate level and commodity level. Iqbal, Bakhsh,

\footnotetext{
*Assistant Professor/Research Economist, Applied Economics Research Centre, University of Karachi.

E-mail:stjawaid@hotmail.com

This paper is a part of Chapter 2 of Syed Tehseen Jawaid's Ph.D. Dissertation.

${ }^{\dagger}$ Associate Professor, Department of Economics \& Finance, University of Bahrain.
} 
Maqbool, and Ahmad (2005) forecast the production and area of wheat in Pakistan by employing ARIMA model. Results indicated that production of wheat would be 29774.8 thousand tons in 2022. On the other hand, area for wheat production would be 8475.1 thousand hectares. Ahmad and Mustafa (2006) forecast production of oranges in Pakistan. They used ARIMA model for forecasting and predicted the production of 2617.45 thousand tons in the year 2023 . Khan, Mustafa, Shah, Khan, and Khan (2008) forecast the production of mangoes in Pakistan by employing ARIMA model, suggesting that production of mangoes would be 1431010 metric tons in 2024. They predicted that mangoes would be available for consumption as well as export. Naz (2013) predicted the date export from Pakistan using ARIMA model. Results indicated that date exports of Pakistan would be 130622 thousand tons in 2025.

Additionally, Ghafoor and Hanif (2005) forecast aggregate exports and imports of Pakistan by employing ARIMA estimation procedure. Findings suggested that exports of Pakistan would be Rs. 418.46 billion, while imports would be Rs. 550.08 billion in 2010. Mehmood and Ahmad (2012) estimated Pakistan's exports to SAARC countries by employing ARIMA estimation. Results revealed that Pakistan's exports to SAARC countries would be worth Rs. 442.07 billion in 2025. It was also predicted that Pakistan's export to SAARC countries would increase by Rs. 27.63 billion per year from 2010 to 2025. Farooqi (2014) forecast aggregate exports and imports of Pakistan by using ARIMA estimation. Results showed that Pakistan's exports and imports would be of Rs. 403.11 billion and Rs. 496.95 billion respectively in 2018. However, only residual uncertainty in considered in ARIMA forecasting, and uncertainty in parameters is ignored (Fuller \& Hasza, 1981; De Luna, 2000). On the other hand, density forecast considers both shock and parameter uncertainty (Akram, Binning, \& Maih, 2016). It is highly doubtful that the outcome overlaps exactly in case of point forecast, so provideing range of uncertainties will be helpful for policy makers to make favorable policies. There are some recent studies that have used Fan chart for forecasting, such as Dowd, Blake, and Cairns (2016), Castillo (2016) and Fukač and Kirkby (2017). Therefore, the objective of the study is to forecast Pakistan's regional trade with Organization of Islamic Cooperation (OIC), Organization for Economic Cooperation and Development (OECD) countries, South Asian Association for Regional Cooperation (SAARC) countries, and Association of South East Asian Nation (ASEAN) countries which have not been forecast before, specifically with an advanced econometric technique like Fan chart. The reason behind the selection of these regions is the hugh percentage share of exports to these regions from Pakistan, which is 78.55 percent of total Pakistani exports on average from 1974 to 2014. Similarly, the percentage share of imports from these regions to Pakistan is 80 percent of the total Pakistani imports on average from 1974 to 2014 . These regions have covered almost $80 \%$ of Pakistan's trade ${ }^{1}$.

To achieve the objective of the study, we have used a newly developed technique namely Fan Chart based on density forecast. Fan chart is a useful tool to forecast with expected uncertainties. There are some other methods of forecasting like seasonal moving average and exponential smoothing, but uncertainty has not been incorporated in them unlike Fan chart.

\section{Contextual Discussion}

In this section, there is brief discussion about regions under consideration in the study namely OIC, OECD, SAARC, and ASEAN.

\footnotetext{
${ }^{1}$ Authors' estimation on the basis of Pakistan Economics Survey (various issues)
} 
Table 1

Pakistan's Share of Exports and Imports with OIC, OECD, SAARC and ASEAN Regions (\%)

\begin{tabular}{lllllllllll}
\hline \multirow{2}{*}{ Decade } & \multicolumn{2}{c}{ Total Share } & \multicolumn{2}{c}{ OIC } & \multicolumn{2}{c}{ OECD } & \multicolumn{2}{c}{ SAARC } & \multicolumn{2}{c}{ ASEAN } \\
& Export & Imports & Export & Imports & Export & Imports & Export & Imports & Export & Imports \\
\hline \multirow{2}{*}{1970 's } & 78.97 & 88.92 & 27.45 & 19.21 & 40.97 & 61.00 & 5.250 & 3.560 & 5.280 & 5.130 \\
1980 's & 80.01 & 87.38 & 25.79 & 25.21 & 46.25 & 54.29 & 4.640 & 1.730 & 3.310 & 6.140 \\
1990 's & 79.22 & 84.10 & 13.05 & 21.01 & 58.31 & 51.19 & 3.610 & 1.750 & 4.230 & 10.13 \\
2000 's & 82.45 & 79.17 & 21.82 & 34.36 & 54.42 & 32.05 & 3.750 & 3.150 & 2.450 & 9.590 \\
2010 & 80.22 & 78.08 & 29.15 & 37.42 & 42.84 & 25.35 & 5.400 & 3.930 & 2.830 & 11.38 \\
2011 & 79.44 & 76.15 & 28.29 & 37.99 & 42.34 & 21.59 & 6.520 & 4.660 & 2.300 & 11.91 \\
2012 & 76.40 & 76.17 & 28.80 & 40.81 & 39.16 & 19.89 & 5.440 & 3.660 & 3.010 & 11.81 \\
2013 & 75.32 & 76.26 & 26.50 & 40.48 & 40.41 & 20.46 & 5.610 & 4.340 & 2.790 & 10.97 \\
2014 & 74.95 & 73.77 & 23.30 & 39.44 & 43.54 & 18.55 & 5.480 & 4.810 & 2.630 & 10.97 \\
\hline \multicolumn{2}{l}{ Source: Authors' Estimation } & & & & & & & & &
\end{tabular}

\section{Organization of Islamic Cooperation}

The Organization of the Islamic Cooperation (OIC) is a worldwide Islamic organization comprising fifty-seven ${ }^{2}$ States founded in 1969. These states are spread on a huge geographical region of four continents including Europe, Africa, Latin America and Asia. These States chose to pool their assets together, join their endeavors and have a unanimous voice to protect the interest and guarantee the advancement and prosperity of their people as well as the Muslims all over the world. Trade has been a major focus cooperation among all the member countries.

Pakistan is located in South Asia with the ranking of 6th most crowded country in the world. It is also one of the confirmed nuclear weapons holding countries. Pakistan is a key member of OIC, Economic Cooperation Organization and D-8 Organization of Economic Cooperation having strong relations with all the Islamic countries.

\section{Organization for Economic Cooperation and Development}

To deal with poor performance of economies in their countries, the political, economic and domestic forces start to think about modification in investment plans which may assist to improve slow economic growth. Therefore, various international and regional organizations have been formed to develop and implement strategies and tactics for their members and other worldwide nations to improve their performance. Organization for Economic Co-Operation and Development (OECD) is one of those international economic development organizations. OECD was founded by 34 countries in 1961. Previously it was recognized as Organization for European Economic Cooperation (OEEC) which was established in 1948 (OECD, 2013). OECD provides a platform to different countries to show their commitment for the market economy and; democracy, compare their policy experiences, and coordinate in international and domestic strategies with related members. Pakistan is one of the active members of OECD.

\section{South Asian Association for Regional Cooperation}

The South Asian Association for Regional Cooperation (SAARC) is an economic and geopolitical association of seven nations (India, Bangladesh, Bhutan, Nepal, Sri Lanka, Maldives and Pakistan) situated in South Asia or Indian subcontinent. In May 1980, the president of Bangladesh Ziaur-rehman brought up the thought of provincial, political, and practical collaboration in South

\footnotetext{
${ }^{2}$ Official website of Organization of Islamic Council: http://www.oic-oci.org/oicv2/home/?lan=en Retrieved 30 December 2015
} 
Asia. Therefore, the first summit was held in Dhaka on 8 December 1985, when the association was secured by the legislatures of eight countries. The association has been extended by including Afghanistan as one new member as well as a few observer states including China, European Union, Japan, Australia, Myanmar, USA, Iran, Mauritius, and South Korea ${ }^{3}$. The SAARC plans to advance welfare financial matters and; cooperative self-assurance among the nations of South Asia, and to speed up socio-economic growth in the region.

The SAARC has created outer relations by creating changeless political relations with the $\mathrm{UN}$ as an observer, the EU and other multilateral bodies. Official gatherings of the pioneers of every country are held on annually, whilst the outside priests meet bi-annually. The 18th SAARC Summit was held in Kathmandu in November 2014.

\section{Association of South East Asian Nation}

The ASEAN was established on 8 august 1967 with its headquarter in Jakarta Indonesia, for political and economic collaboration by the joint venture of ten Southeast Asian countries including Indonesia, Malaysia, Philippines, Singapore, Thailand, Brunei, Cambodia, Laos, Myanmar, and Vietnam. The main purpose of ASEAN is to enhance social progress, economic growth and sociocultural revolution, protect regional peace and stability, and provide opportunities to member countries for discussion on differences peacefully.

\section{Pakistan's Regional Trade Performance}

There are a number of aspects through which a country's performance has been observed. In this section, some trade related aspects have been discussed in the context of Pakistan. In addition, we will discuss Pakistan's trade performance with selected regions namely OIC, OECD, ASEAN, and SAARC.

The balance of payments is seen as an essential marker of the developing financial activities in all the countries. Therefore, the balance of payments is the measurable (Statistical) record of all transactions occurring between a country's inhabitants and rest of the world in a particular period. The balance of payments has been a sign of trouble in developing countries, particularly in Pakistan, where it has been a serious issue in the recent times.

Pakistan has been experiencing trade deficits since 1947. As it is a developing country, the balance of payments has not been very sustainable. Pakistan's visible and invisible imports have exceed its exports throughout the years, except during a brief period of 1951 to 1957 and the year $1973^{4}$.

It has been observed that five primary commodities including raw jute, raw wool, hides, cotton, and tea accounted for 99\% of Pakistan's export earnings since the time of independence till 1949. In this way, Pakistan fits the unusual example as an unindustrialized undeveloped nation, and the cause of this accomplishment was delivering and sending out just Primary items and primarily reliant on sufficient climatic conditions in the early years. Pakistan's economic strategies moved towards an accentuation on industrialization which became the catalyst for an economic change. thus,the $99 \%$ contribution of 5 main commodities had fallen to $75 \%$ in 1958-9 and the main cause was the shift in the direction of trade towards dependence on Indian imported goods including cotton yarn, consumer goods, and textiles (Zaidi, 2005).

\footnotetext{
${ }^{3}$ (SAARC Summit press, 2013)

${ }^{4}$ Handbook of Statistics of Pakistan Economy (2015) p. 790
} 
The importance of industry was further recognized in the era of growth under Ayub Khan and the way of production changed. Pakistan started to export outside the developed countries, while the developed nations now had a decision to purchase products from different sources. Figure 1 is a synopsis of balance of trade from 1974 to 2014, demonstrating the main earnings and expenses associated with exports and imports respectively. The trade balance has generally been in the negative, suggesting that imports have been more prominent than exports.

Furthermore, the details of Pakistan's imports and exports from 1974 to 2014 (latest statistics available) are shown through Figure 1. This Figure demonstrates that Pakistan's total trade comprising of real imports and real exports has increased about 872 percent from 1974 to 2014 .

Figure 1

Exports, Imports, and Trade Balance 1974-2014 (Million Rs)

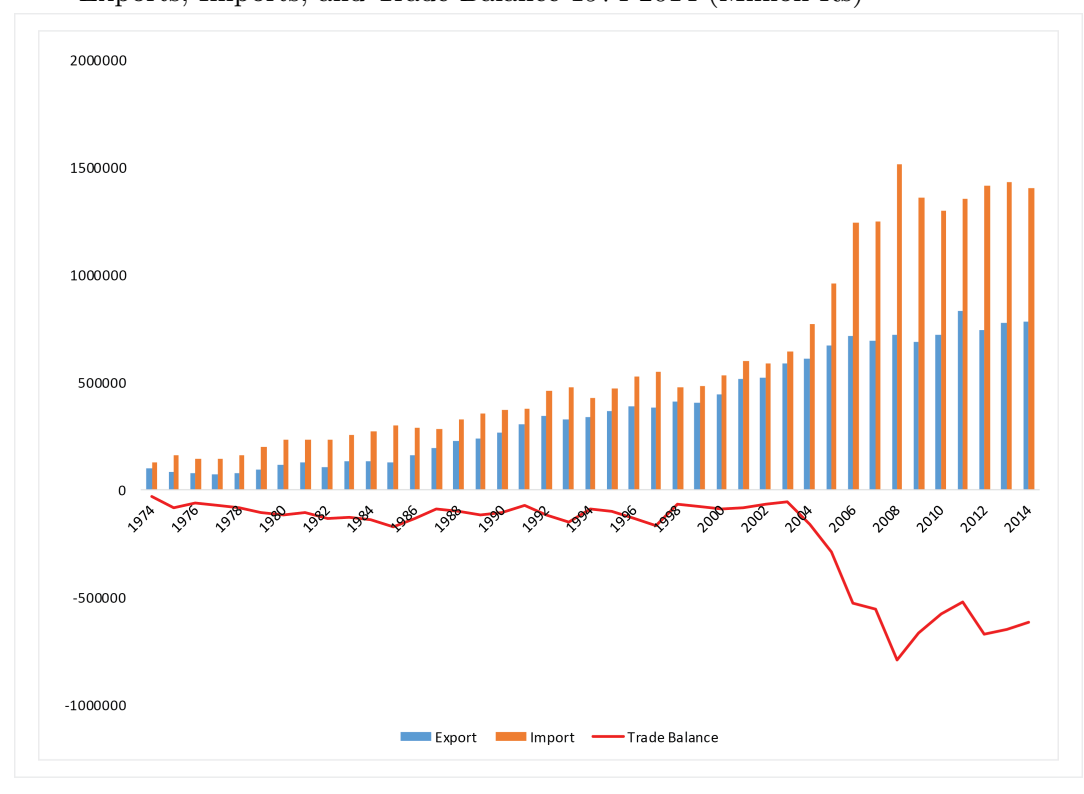

Furthermore, the details of Pakistan's imports and exports from 1974 to 2014 (latest statistics available) are shown through Figure 1. This figure demonstrates that Pakistan's trade (real imports and real exports) has increased by about 872 percent from 1974 to 2014 . It can be observed that from 2005-14 the trade deficit has increased compared to previous 10 years largely driven by the import of consumer items and higher international crude oil. Hence Figure 1 suggests that the balance of trade has been pessimistic in Pakistan as its imports are more than its export.

Additionally, the changing pattern of exports and imports from 1974 to 2014 can be easily observed through Figure $2 \& 3$ respectively. It can be seen that manufactured goods contributed $70 \%$, primary commodities $16 \%$ and semi-manufacturer, $14 \%$ to the total exports of Pakistan in 2014. 


\section{Figure 2}

Economic Classification of Exports (in percentage)

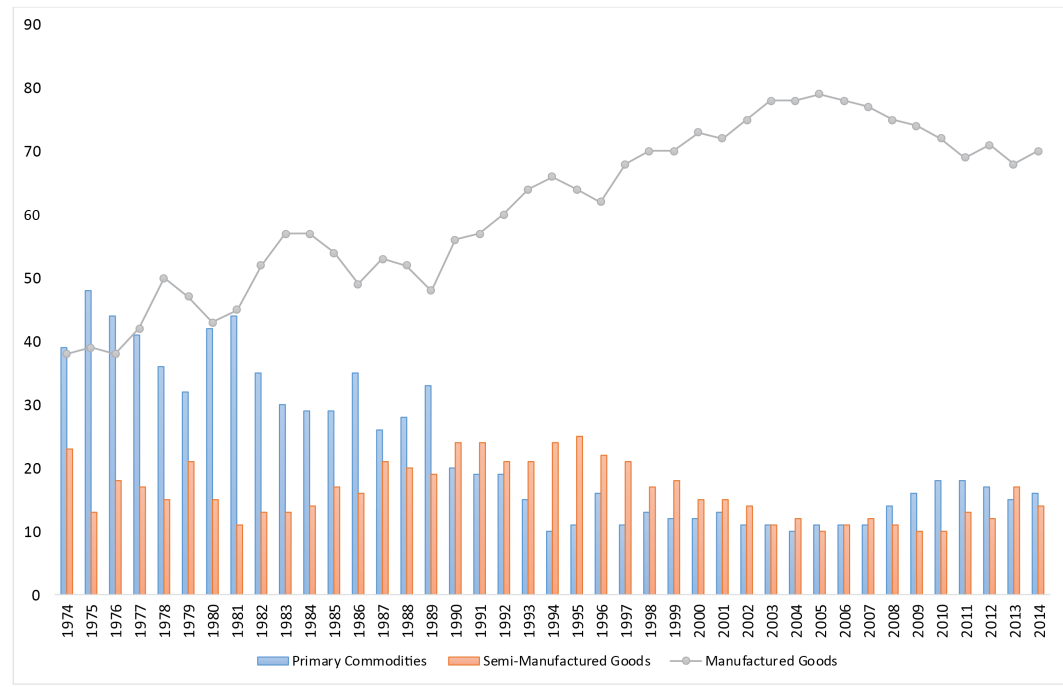

Figure 3

Economic Classification of Imports (in percentage)

60

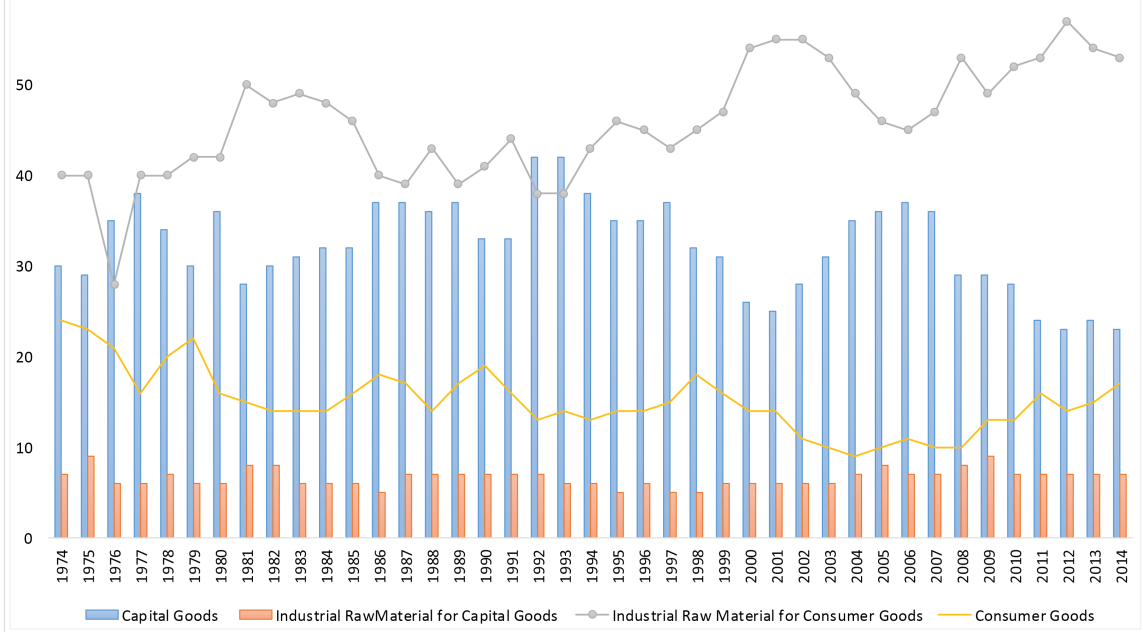

On the other hand, consumer goods contributed $17 \%$, capital goods $23 \%$, industrial raw material of capital good $7 \%$, whereas industrial raw material of consumer good iscontributed the largest share at $53 \%$ to the imports of Pakistan in 2014.

Foreign exchange reserves (FER) are considered a measure of financial strength of a country. Figure 5 shows volatility in Pakistan's foreign exchange reserve throughout the period. There is 
an increase in foreign exchange reserve during 2001 to 2004, 2006 and 2008 to 2011. On the other hand, there is sharp decline in 2007-2008 and after 2011. It has increased in 2014.

Figure 4

Foreign Exchange Reserve (Rs. Millions)

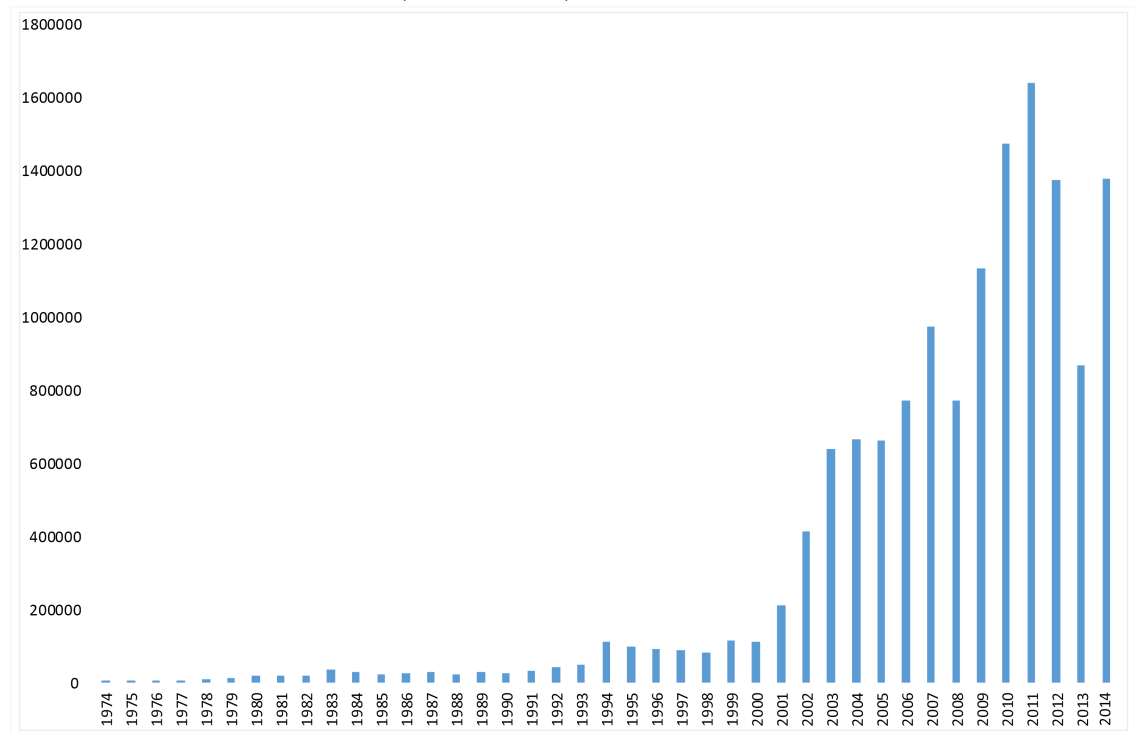

Pakistan-OIC trade has always played a vital role in Pakistan's international trade. Pakistan's exports have considerably increased in the last decade with these countries. Imports have also increased at a high rate in these years. Among these countries, U.A.E has $9 \%$ and $7 \%$ share of total exports in 2010 and 2014 respectively ${ }^{5}$.

Pakistan's trade performance with SAARC countries is in a better condition. Here deficit has not increased consistently, instead Pakistan has enjoyed trade surplus in some years between 1975 to 2000 and in 2003. However, after 2003, Pakistan has been facing trade deficit continuously.

Pakistan's trade performance with ASEAN countries is not healthy. Here deficit has increased consistently from 1974 trade deficit has increased to 2005. Trade surplus has been noticed in 2006 and after 2006, Pakistan has been facing drastic escalation in trade deficit.

\footnotetext{
${ }^{5}$ Pakistan Economic Survey 2014-15, p. 143
} 
Figure 5

Exports, Imports and Trade Balance with OIC Countries (Millions Rs.)

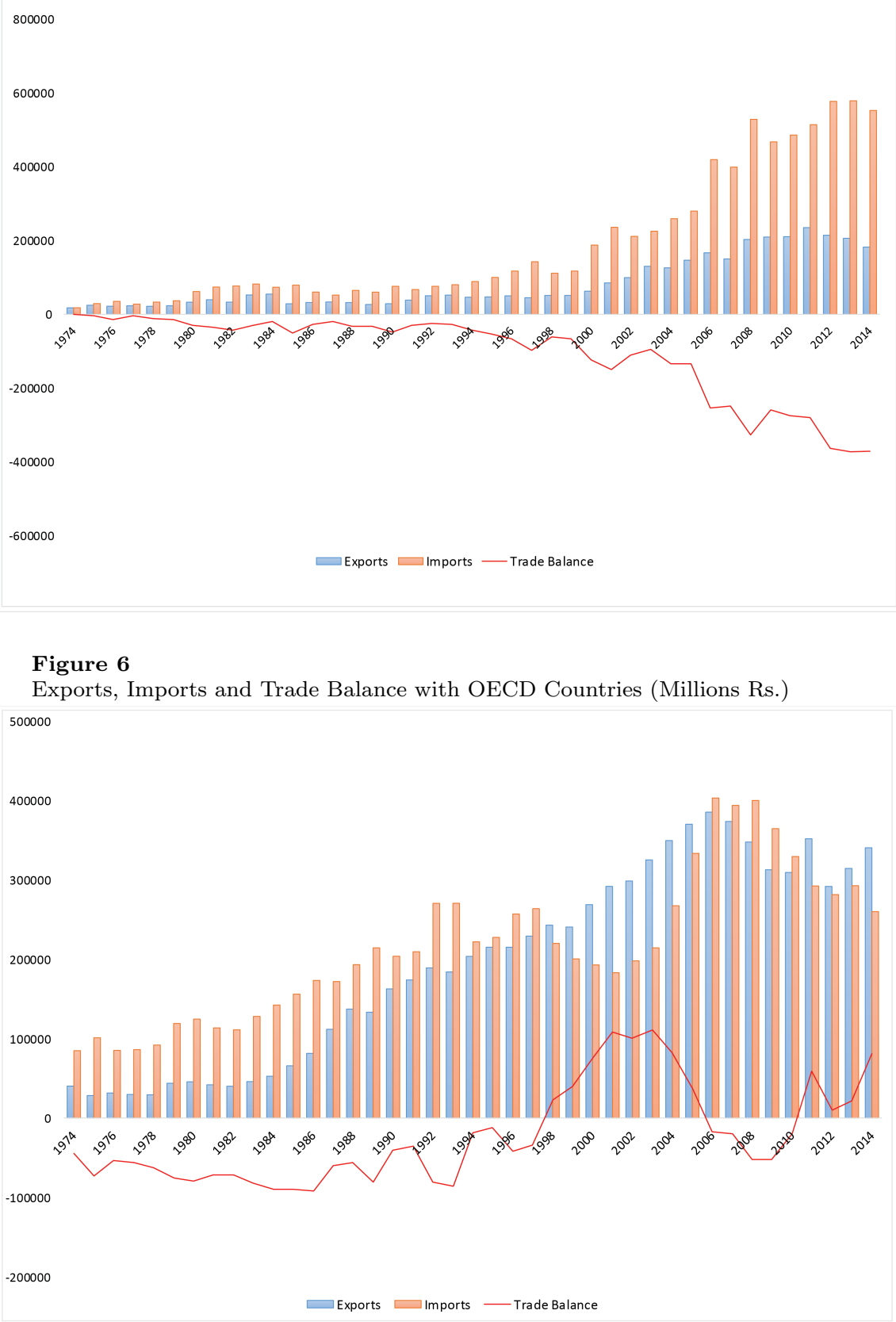




\section{Figure 7}

Exports, Imports and Trade Balance with SAARC Countries (Millions Rs.)

80000

40000

20000

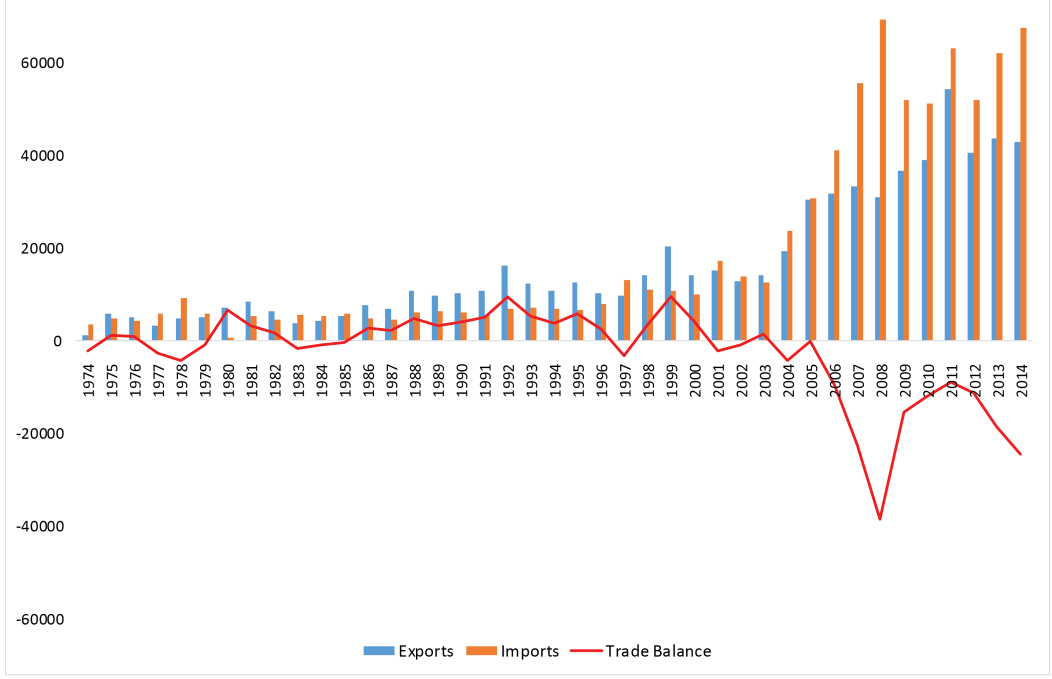

Figure 8

Exports, Imports and Trade Balance with ASEAN Countries (Millions Rs.)

200000

150000

100000

50000

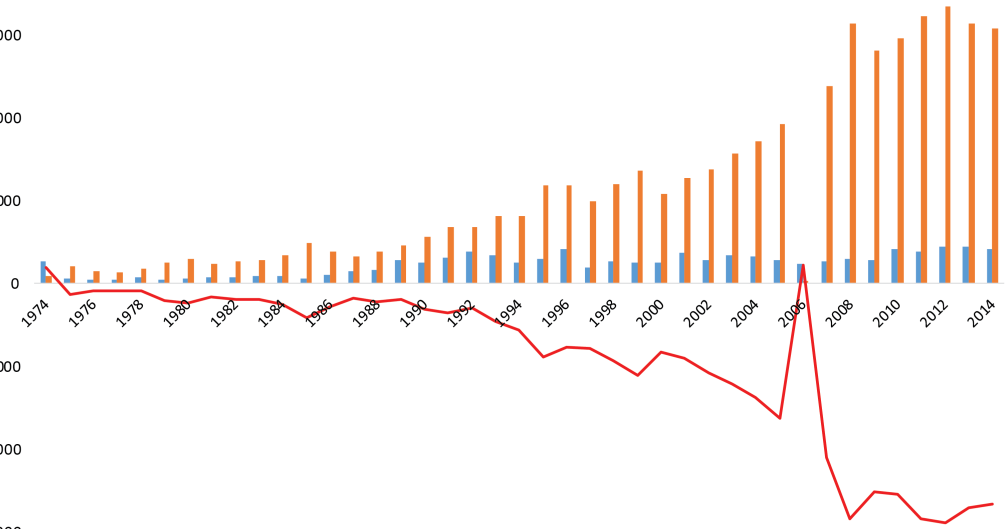

$-150000$

$-200000$

Exports Imports - Trade Balance 


\section{Methodology}

Economic forecast fundamentally faces the problem of uncertainty. Nobody can predict future with complete certainty because forecast is always bound by different assumptions and a variety of upside and downside risks. The uncertainty is one of the main causes of bad forecast outcomes and it can even cause major failures in forecasting. Although forecasting methodologies have developed extensively, the problem of uncertainty has not been resolved efficiently in economic forecasting.

Fan chart is a device that can represent uncertainty conditions over time. The fan chart uses different type of lines and shades in graphical representation of the density forecast to show different percentiles of estimated probability distribution. When forecast uncertainties increase over time, the band for same percentile becomes broader, making the presentation of the graph appear like a wider fan over time.

Fan chart has become a popular technique for economists in forecasting economic indicators. The monetary policy committee of Bank of England used fan chart for the first time in its inflation report published in 1996. Since then, fan chart has been extensively used to forecast other aspects of economy including prediction of growth rate of gross domestic product and other indicators. Since 2006, International Monetary Fund (IMF) has also used Fan chart for world GDP growth forecast. In this study, growth in aggregate and regional trade is forecast for the period of 2015 to 2020 .

By employing the methodology of Kannan and Elekdag (2009), following steps have been used to produce fan chats for growth in aggregate and regional trade:

1. Determine the growth forecast for aggregate and regional trade (denoted as $y$ ).

2. Uncertainty parameter is computed as historical forecast error variance (denoted as $\delta y$ ).

3. For producing skewed fan chart, Pearson skewness indicator (denoted as $\gamma y$ ) is computed.

4. The confidence levels (q) i.e. 90 percent, 60 percent and 30 percent, are chosen to be displayed in the fan chart.

5. When variance $\left(\delta_{y}\right)$ and skewness $\left(\gamma_{y}\right)$ parameters are established, they characterize forecast distribution in terms of parameters of the 2-piece normal distribution (i.e. the mean $(\mu)$ which represents the central forecast and the left $\left(\delta_{1}\right)$ and right $\left(\delta_{2}\right)$ standard deviation of said distribution.

The density function of 2-piece normal distribution (combination of 2 halves of normal distribution with same mean $(\mu)$ and different deviations $\left(\delta_{1}\right.$ and $\left.\delta_{2}\right)$ on each side) is presented by:

$$
\begin{aligned}
& f(y)=A \exp \left\{-\frac{(y-\mu)^{2}}{2 \delta_{1}^{2}}\right\} \text { for } y \leq \mu \\
& f(y)=A \exp \left\{-\frac{(y-\mu)^{2}}{2 \delta_{2}^{2}}\right\} \text { for } y>\mu
\end{aligned}
$$

Where,

$$
A=\frac{\sqrt{2}\left(\delta_{1}+\delta_{2}\right)^{-1}}{\sqrt{\pi}}
$$


Here $\mu$ represents the mode of distribution if $\delta_{1} \neq \delta_{2}$ (i.e. distribution is skewed). Following are the equations which represent mean, variance, and skewness of two-piece normal distribution respectively:

$$
\begin{gathered}
E(y)=\mu+\sqrt{\frac{2}{\pi}}\left(\delta_{2}-\delta_{1}\right) \\
V(y)=\delta_{1} \delta_{2}+\left(1-\frac{2}{\pi}\right)\left(\delta_{2}-\delta_{1}\right)^{2} \\
\gamma(y)=\sqrt{\frac{2}{\pi}}\left(\delta_{2}-\delta_{1}\right)\left[\left(\frac{4}{\pi}-1\right)\left(\delta_{2}-\delta_{1}\right)^{2}+\delta_{1} \delta_{2}\right]
\end{gathered}
$$

Where $\mathrm{E}(\mathrm{y}), \mathrm{V}(\mathrm{y})$ and $\gamma(\mathrm{y})$ represent the mean, variance and skewness of 2-piece normal distribution respectively. Blix and Sellin (1998) discussed that the skewness of 2-piece normal distribution (since skewness and variance are uniquely identified) could be approximately calculated as:

$$
\gamma(y)=\sqrt{\frac{2}{\pi}}\left(\delta_{2}-\delta_{1}\right)
$$

This form of skewness of 2-piece normal distribution simplifies our calculation of $\delta_{1}$ and $\delta_{2}$ for constructing confidence interval and Fan chart. Now we can solve $\delta_{1}$ and $\delta_{2}$ from $\mathrm{V}(\mathrm{y})$ and $\gamma(\mathrm{y})$. By substituting $\delta_{2}$ in $\mathrm{V}(\mathrm{y})$ with skewness from $\gamma(\mathrm{y})$ and $\delta_{1}$ we get the following equation:

$$
\delta_{1}^{2}+\sqrt{\frac{\pi}{2}} \gamma_{y} \delta_{1}-\left[\left(1-\frac{\pi}{2}\right) \gamma_{y}^{2}+\delta_{y}^{2}\right]=0
$$

Where $\gamma_{y}$ and $\delta_{y}$ are estimated skewness and variance of 2-piece normal distribution respectively. Once we determine $\delta_{1}$, the right hand side standard deviation of the distribution, $\delta_{2}$ can be determined by the approximation of equation 7 .

6. The confidence interval surrounding each point estimate of aggregate and regional trade growth can be drawn for each level of confidence $(q)$, by solving for

$$
\begin{gathered}
z_{1}=\mu-\frac{\delta_{1}}{\delta_{2}}\left(z_{2}-\mu\right) \\
z_{2}=\mu-\delta_{2} \psi^{-1}\left(\frac{1+q}{2}\right)
\end{gathered}
$$

Where $\psi^{-1}\left(0<\psi^{-1}<1\right)$ is the inverse of standard normal distribution. For more details on the procedure, see Camilleri and Vella (2015) and Yu (2011). All the data have been gathered from Pakistan Economic Surveys (various issues) and Handbook of statistics of Pakistan Economy (2015).

\section{Fan Chart Analysis}

In this section, trade forecasting is discussed at aggregate level as well as regional trade level. In the umbrella of trade, here we discuss aggregate and region wise export, import and trade balance of Pakistan. 


\section{Figure 9}

Fan Chart of Export Growth Rate

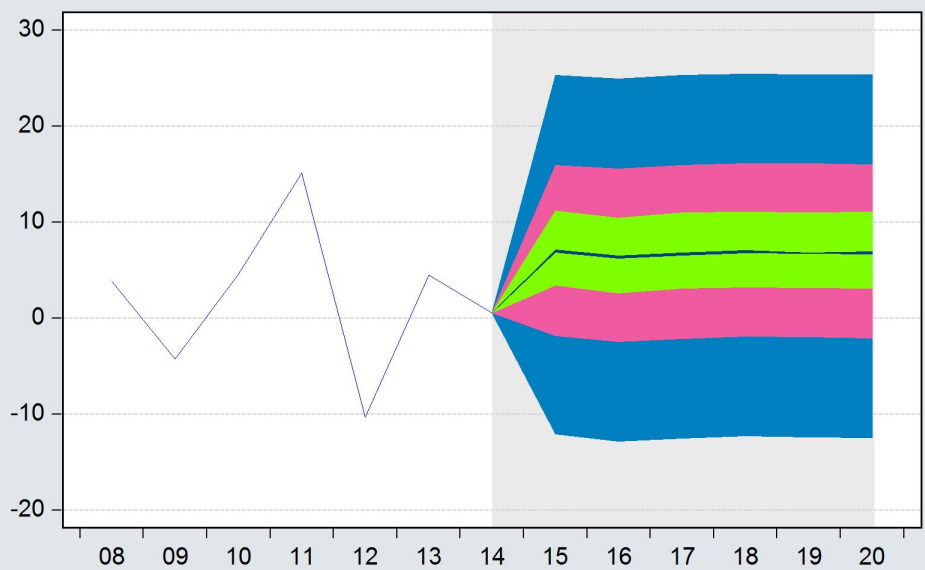

\begin{tabular}{|l||l||l|}
$90 \%$ Confidence Interval & $60 \%$ Confidence Interval & $30 \%$ Confidence Interval \\
\hline
\end{tabular}

\section{Figure 10}

Fan Chart of Import Growth Rate

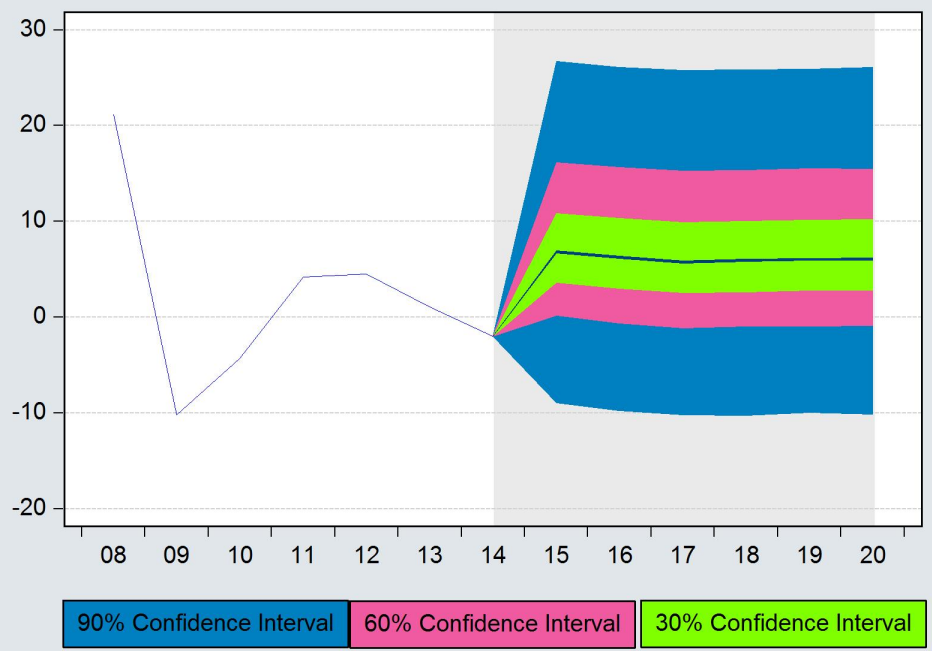




\section{Figure 11}

Fan Chart of Trade Balance Growth Rate

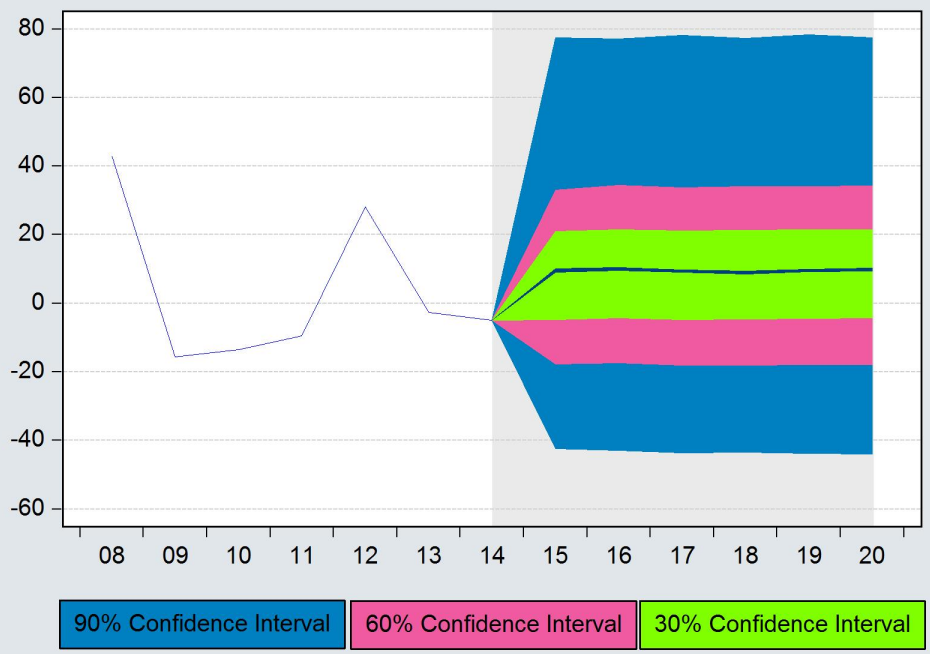

\section{Aggregate Trade}

From Table 2, 3 and 4, and Figure 9, 10 and 11, it is evident that the average growth rate of exports from 2015 to 2020 will be 6.76 percent. Skewness shows a downside risk in all the forecast years except in 2018. This indicates an alarming risk situation in total export performance in the coming years. On the other hand, average import growth is predicted to be 7.05 percent from 2015 to 2020. The average growth in trade balance (deficit) will be 10.77 percent from 2015 to 2020 . Skewness of all forecast years shows an upside risk which indicate that the increase in imports will be higher than the increase in exports.

Table 2

Results of Fan Chart of EXPORT Growth

\begin{tabular}{|c|c|c|c|c|c|c|c|c|c|c|c|c|}
\hline Year & \multicolumn{2}{|c|}{2015} & \multicolumn{2}{|c|}{2016} & \multicolumn{2}{|c|}{2017} & \multicolumn{2}{|c|}{2018} & \multicolumn{2}{|c|}{2019} & \multicolumn{2}{|c|}{2020} \\
\hline Growth Rate & \multicolumn{2}{|c|}{6.967} & \multicolumn{2}{|c|}{6.359} & \multicolumn{2}{|c|}{6.724} & \multicolumn{2}{|c|}{6.914} & \multicolumn{2}{|c|}{6.835} & \multicolumn{2}{|c|}{6.804} \\
\hline Std. Deviation & \multicolumn{2}{|c|}{11.25} & \multicolumn{2}{|c|}{11.37} & \multicolumn{2}{|c|}{11.39} & \multicolumn{2}{|c|}{11.35} & \multicolumn{2}{|c|}{11.38} & \multicolumn{2}{|c|}{11.39} \\
\hline Skewness & \multicolumn{2}{|c|}{-0.072} & \multicolumn{2}{|c|}{-0.062} & \multicolumn{2}{|c|}{-0.071} & \multicolumn{2}{|c|}{0.07} & \multicolumn{2}{|c|}{-0.068} & \multicolumn{2}{|c|}{-0.072} \\
\hline Confidence Interval & Lower & Upper & Lower & Upper & Lower & Upper & Lower & Upper & Lower & Upper & Lower & Upper \\
\hline 30 percent & 3.422 & 11.14 & 2.603 & 10.39 & 3.063 & 10.93 & 3.206 & 11.04 & 3.186 & 10.98 & 3.076 & 11.02 \\
\hline 60 percent & -1.857 & 15.91 & -2.449 & 15.53 & -2.14 & 15.875 & -1.9 & 16.07 & -1.993 & 16.10 & -2.095 & 15.98 \\
\hline 90 percent & -12.07 & 25.30 & -12.86 & 24.92 & -12.55 & 25.27 & -12.28 & 25.38 & -12.42 & 25.35 & -12.44 & 25.31 \\
\hline
\end{tabular}


Table 3

Results of Fan Chart of IMPORT Growth

\begin{tabular}{|c|c|c|c|c|c|c|c|c|c|c|c|c|}
\hline Year & \multicolumn{2}{|c|}{2015} & \multicolumn{2}{|c|}{2016} & \multicolumn{2}{|c|}{2017} & \multicolumn{2}{|c|}{2018} & \multicolumn{2}{|c|}{2019} & \multicolumn{2}{|c|}{2020} \\
\hline Growth Rate & \multicolumn{2}{|c|}{7.766} & \multicolumn{2}{|c|}{7.152} & \multicolumn{2}{|c|}{6.712} & \multicolumn{2}{|c|}{6.813} & \multicolumn{2}{|c|}{6.939} & \multicolumn{2}{|c|}{6.958} \\
\hline Std. Deviation & \multicolumn{2}{|c|}{10.644} & \multicolumn{2}{|c|}{10.748} & \multicolumn{2}{|c|}{10.777} & \multicolumn{2}{|c|}{10.806} & \multicolumn{2}{|c|}{10.75} & \multicolumn{2}{|c|}{10.832} \\
\hline Skewness & \multicolumn{2}{|c|}{0.279} & \multicolumn{2}{|c|}{0.252} & \multicolumn{2}{|c|}{0.271} & \multicolumn{2}{|c|}{0.243} & \multicolumn{2}{|c|}{0.253} & \multicolumn{2}{|c|}{0.25} \\
\hline Confidence Interval & Lower & Upper & Lower & Upper & Lower & Upper & Lower & Upper & Lower & Upper & Lower & Upper \\
\hline 30 percent & 3.611 & 10.805 & 3.024 & 10.337 & 2.557 & 9.876 & 2.64 & 10.035 & 2.785 & 10.133 & 2.792 & 10.19 \\
\hline 60 percent & 0.201 & 16.13 & -0.643 & 15.656 & -1.121 & 15.234 & -0.949 & 15.34 & -0.916 & 15.504 & -0.896 & 15.471 \\
\hline 90 percent & -8.954 & 26.69 & -9.796 & 26.115 & -10.189 & 25.802 & -10.29 & 25.855 & -9.974 & 25.88 & -10.136 & 26.081 \\
\hline
\end{tabular}

Source: Authors' Estimation

Table 4

Results of Fan Chart of TB Growth

\begin{tabular}{|c|c|c|c|c|c|c|c|c|c|c|c|c|}
\hline Year & \multicolumn{2}{|c|}{2015} & \multicolumn{2}{|c|}{2016} & \multicolumn{2}{|c|}{2017} & \multicolumn{2}{|c|}{2018} & \multicolumn{2}{|c|}{2019} & \multicolumn{2}{|c|}{2020} \\
\hline Growth Rate & \multicolumn{2}{|c|}{10.691} & \multicolumn{2}{|c|}{11.07} & \multicolumn{2}{|c|}{10.666} & \multicolumn{2}{|c|}{10.592} & \multicolumn{2}{|c|}{10.853} & \multicolumn{2}{|c|}{10.82} \\
\hline Std. Deviation & \multicolumn{2}{|c|}{35.729} & \multicolumn{2}{|c|}{35.81} & \multicolumn{2}{|c|}{36.245} & \multicolumn{2}{|c|}{36.058} & \multicolumn{2}{|c|}{36.375} & \multicolumn{2}{|c|}{36.14} \\
\hline Skewness & \multicolumn{2}{|c|}{0.448} & \multicolumn{2}{|c|}{0.392} & \multicolumn{2}{|c|}{0.425} & \multicolumn{2}{|c|}{0.415} & \multicolumn{2}{|c|}{0.417} & \multicolumn{2}{|c|}{0.381} \\
\hline Confidence Interval & Lower & Upper & Lower & Upper & Lower & Upper & Lower & Upper & Lower & Upper & Lower & Upper \\
\hline 30 percent & -4.87 & 20.853 & -4.271 & 21.547 & -4.775 & 21.199 & -4.526 & 21.299 & -4.5 & 21.409 & -4.278 & 21.496 \\
\hline 60 percent & -17.708 & 33.073 & -17.475 & 34.421 & -18.129 & 33.655 & -18.091 & 34.15 & -17.982 & 34.101 & -17.865 & 34.236 \\
\hline 90 percent & -42.403 & 77.483 & -42.86 & 77.103 & -43.561 & 78.086 & -43.41 & 77.368 & -43.729 & 78.385 & -43.921 & 77.383 \\
\hline
\end{tabular}

\section{Trade with OIC Countries}

Tables 5, 6 and 7 and Figures 12, 13 and 14 show that; the average growth rate of export to OIC (EOIC) from 2015 to 2020 will be 8.11 percent. Skewness shows an upside risk in all the forecast years. This indicates chances of betterment in EOIC in coming years. On the other hand, the average growth in imports from OIC (IOIC) growth is 10.29 percent from 2015 to 2020 . Skewness shows upside risk in all projected years. Average growth in trade balance (deficit) ${ }^{6}$ will be 22.72 percent from 2015 to 2020 . Skewness of all forecasted years show upside risk which indicates that the increase in imports will be higher than increase in exports.

\footnotetext{
${ }^{6}$ TOIC is growth in trade deficit with $\mathrm{OIC}$
} 


\section{Figure 12}

Fan Chart of EOIC Growth Rate

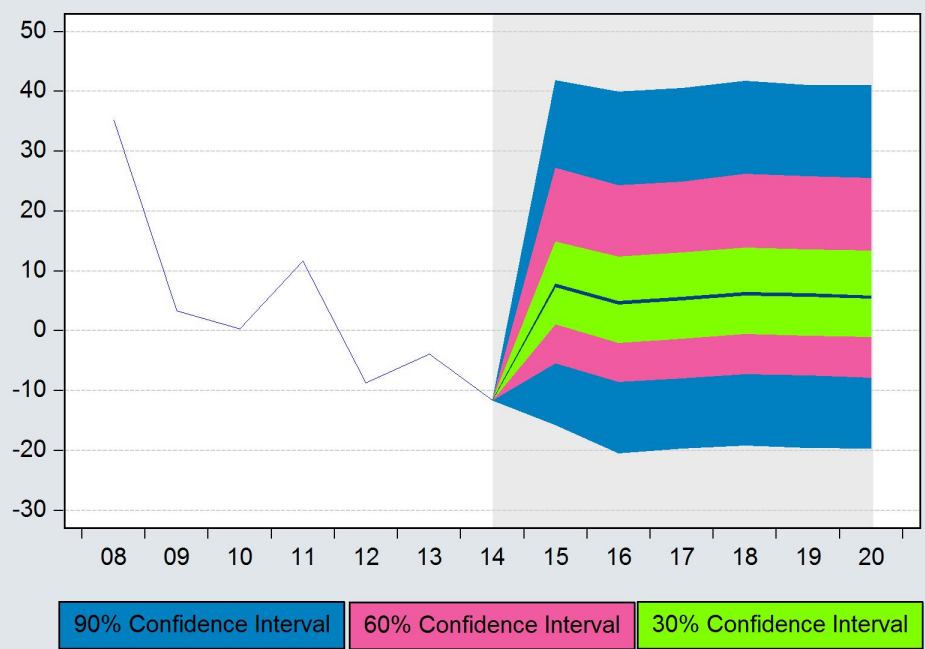

Figure 13

Fan Chart of IOIC Growth Rate

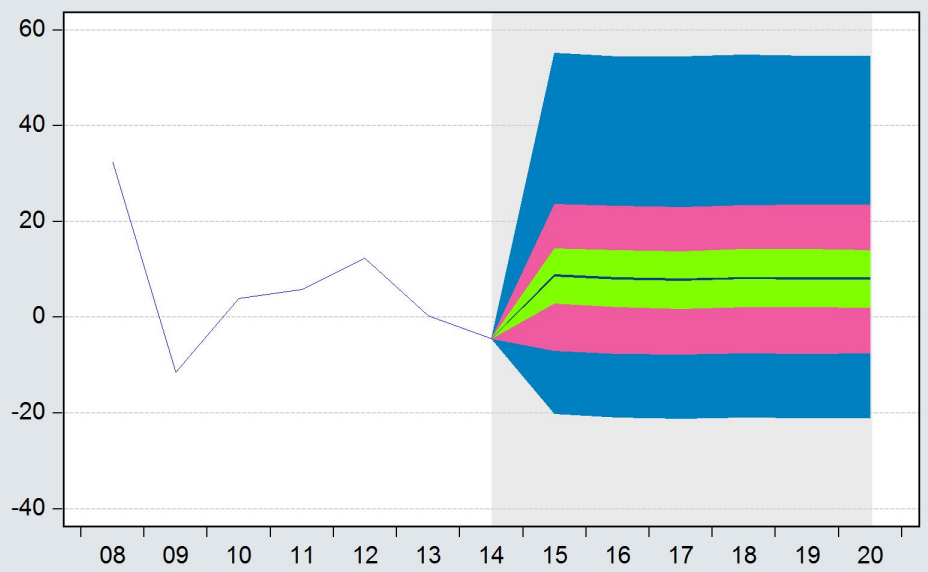

\begin{tabular}{|l|l||l|l}
$90 \%$ Confidence Interval & $60 \%$ Confidence Interval & $30 \%$ Confidence Interval \\
\hline
\end{tabular} 


\section{Figure 14}

Fan Chart of TOIC Growth Rate

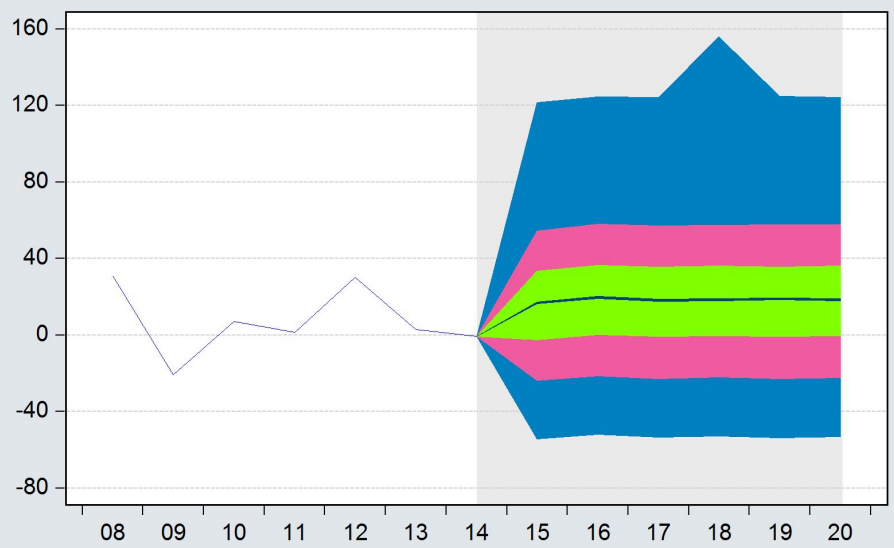

$90 \%$ Confidence Interval $60 \%$ Confidence Interval $30 \%$ Confidence Interval

Table 5

Results of Fan Chart of EOIC Growth

\begin{tabular}{|c|c|c|c|c|c|c|c|c|c|c|c|c|}
\hline Year & \multicolumn{2}{|c|}{2015} & \multicolumn{2}{|c|}{2016} & \multicolumn{2}{|c|}{2017} & \multicolumn{2}{|c|}{2018} & \multicolumn{2}{|c|}{2019} & \multicolumn{2}{|c|}{2020} \\
\hline Growth Rate & \multicolumn{2}{|c|}{9.894} & \multicolumn{2}{|c|}{6.888} & \multicolumn{2}{|c|}{7.534} & \multicolumn{2}{|c|}{8.414} & \multicolumn{2}{|c|}{8.09} & \multicolumn{2}{|c|}{7.847} \\
\hline Std. Deviation & \multicolumn{2}{|c|}{18.2} & \multicolumn{2}{|c|}{18.878} & \multicolumn{2}{|c|}{18.846} & \multicolumn{2}{|c|}{19.071} & \multicolumn{2}{|c|}{18.959} & \multicolumn{2}{|c|}{19.015} \\
\hline Skewness & \multicolumn{2}{|c|}{0.426} & \multicolumn{2}{|c|}{0.381} & \multicolumn{2}{|c|}{0.385} & \multicolumn{2}{|c|}{0.383} & \multicolumn{2}{|c|}{0.359} & \multicolumn{2}{|c|}{0.376} \\
\hline Confidence Interval & Lower & Upper & Lower & Upper & Lower & Upper & Lower & Upper & Lower & Upper & Lower & Upper \\
\hline 30 percent & 1.105 & 14.888 & -1.947 & 12.359 & -1.321 & 13.027 & -0.519 & 13.85 & -0.772 & 13.525 & -1.006 & 13.406 \\
\hline 60 percent & -5.34 & 27.156 & -8.529 & 24.288 & -7.94 & 24.893 & -7.235 & 26.161 & -7.397 & 25.759 & -7.762 & 25.471 \\
\hline 90 percent & -15.707 & 41.842 & -20.406 & 39.928 & -19.632 & 40.539 & -19.085 & 41.741 & -19.496 & 41.052 & -19.638 & 41.048 \\
\hline
\end{tabular}

Source: Authors' Estimation

Table 6

Results of Fan Chart of IOIC Growth

\begin{tabular}{|c|c|c|c|c|c|c|c|c|c|c|c|c|}
\hline Year & \multicolumn{2}{|c|}{2015} & \multicolumn{2}{|c|}{2016} & \multicolumn{2}{|c|}{2017} & \multicolumn{2}{|c|}{2018} & \multicolumn{2}{|c|}{2019} & \multicolumn{2}{|c|}{2020} \\
\hline Growth Rate & \multicolumn{2}{|c|}{10.788} & \multicolumn{2}{|c|}{10.203} & \multicolumn{2}{|c|}{9.985} & \multicolumn{2}{|c|}{10.309} & \multicolumn{2}{|c|}{10.244} & \multicolumn{2}{|c|}{10.213} \\
\hline Std. Deviation & \multicolumn{2}{|c|}{22.321} & \multicolumn{2}{|c|}{22.358} & \multicolumn{2}{|c|}{22.407} & \multicolumn{2}{|c|}{22.455} & \multicolumn{2}{|c|}{22.422} & \multicolumn{2}{|c|}{22.422} \\
\hline Skewness & \multicolumn{2}{|c|}{0.739} & \multicolumn{2}{|c|}{0.72} & \multicolumn{2}{|c|}{0.727} & \multicolumn{2}{|c|}{0.728} & \multicolumn{2}{|c|}{0.712} & \multicolumn{2}{|c|}{0.714} \\
\hline Confidence Interval & Lower & Upper & Lower & Upper & Lower & Upper & Lower & Upper & Lower & Upper & Lower & Upper \\
\hline 30 percent & 2.874 & 14.333 & 2.201 & 13.934 & 1.769 & 13.729 & 2.156 & 14.154 & 2.139 & 14.137 & 2.103 & 13.921 \\
\hline 60 percent & -6.971 & 23.599 & -7.586 & 23.197 & -7.677 & 23.026 & -7.423 & 23.322 & -7.614 & 23.518 & -7.481 & 23.433 \\
\hline 90 percent & -20.123 & 55.162 & -20.91 & 54.471 & -21.154 & 54.401 & -20.891 & 54.831 & -20.957 & 54.524 & -21.071 & 54.538 \\
\hline
\end{tabular}

Source: Authors' Estimation 
Table 7

Results of Fan Chart of TOIC Growth

\begin{tabular}{|c|c|c|c|c|c|c|c|c|c|c|c|c|}
\hline Year & \multicolumn{2}{|c|}{2015} & \multicolumn{2}{|c|}{2016} & \multicolumn{2}{|c|}{2017} & \multicolumn{2}{|c|}{2018} & \multicolumn{2}{|c|}{2019} & \multicolumn{2}{|c|}{2020} \\
\hline Growth Rate & \multicolumn{2}{|c|}{20.27} & \multicolumn{2}{|c|}{23.12} & \multicolumn{2}{|c|}{21.92} & \multicolumn{2}{|c|}{26.38} & \multicolumn{2}{|c|}{22.31} & \multicolumn{2}{|c|}{22.34} \\
\hline Std. Deviation & \multicolumn{2}{|c|}{52.96} & \multicolumn{2}{|c|}{53.23} & \multicolumn{2}{|c|}{53.61} & \multicolumn{2}{|c|}{62.44} & \multicolumn{2}{|c|}{53.85} & \multicolumn{2}{|c|}{53.55} \\
\hline Skewness & \multicolumn{2}{|c|}{0.583} & \multicolumn{2}{|c|}{0.572} & \multicolumn{2}{|c|}{0.579} & \multicolumn{2}{|c|}{0.985} & \multicolumn{2}{|c|}{0.569} & \multicolumn{2}{|c|}{0.568} \\
\hline Confidence Interval & Lower & Upper & Lower & Upper & Lower & Upper & Lower & Upper & Lower & Upper & Lower & Upper \\
\hline 30 percent & -2.541 & 33.33 & 0.201 & 36.51 & -0.886 & 35.36 & -0.407 & 36.09 & -0.759 & 35.46 & -0.435 & 36.13 \\
\hline 60 percent & -23.85 & 54.43 & -21.35 & 58.01 & -22.82 & 56.96 & -22.11 & 57.51 & -22.81 & 57.60 & -22.32 & 57.62 \\
\hline 90 percent & -54.26 & 121.5 & -51.88 & 124.5 & -53.53 & 124.2 & -52.81 & 155.8 & -53.64 & 124.8 & -53.24 & 124.2 \\
\hline
\end{tabular}

Source: Authors' Estimation

\section{Trade with OECD Countries}

Tables 8, 9 and 10 and Figures 15, 16 and 17 show, the projected average growth rate of export to OECD (EOECD) from 2015 to 2020 to be 6.81 percent. Similarly, skewness shows an upside risk in all the forecast years. This indicates chances of betterment in EOECD in coming years. On the other hand, average growth in import from OECD (IOECD) is 3 percent from 2015 to 2020. Skewness shows a downside risk in all the projected years. The average growth in trade balance (deficit) ${ }^{7}$ is predicted to be -16.33 percent from 2015 to 2020 . Skewness of all the forecast years shows a downside risk, except in 2018, which indicates that the increase in EOECD will be higher than increase in IOECD. The upside risk in EOECD and downside risk in IOECD are also a sign that trade deficit will be less during 2015 to 2020.

Figure 15

Fan Chart of EOECD Growth Rate

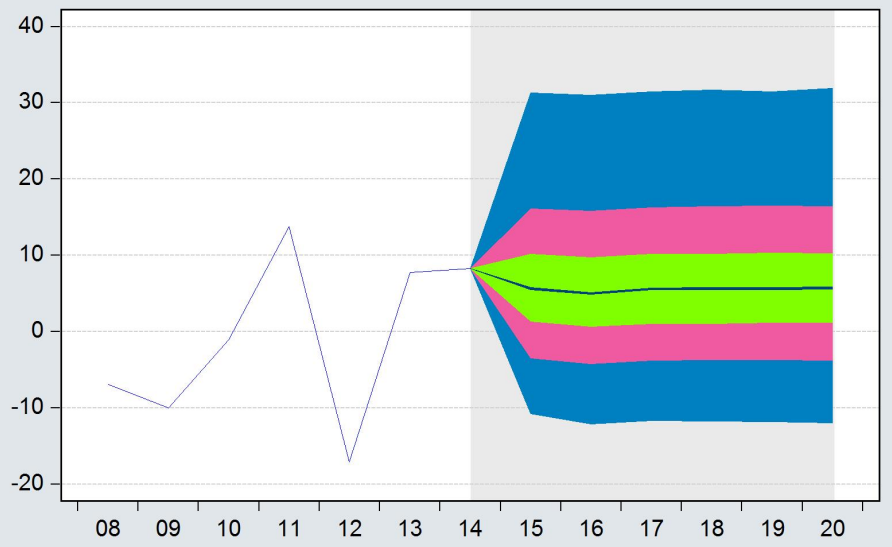

\begin{tabular}{|l|l|l|l}
$90 \%$ Confidence Interval & $60 \%$ Confidence Interval & $30 \%$ Confidence Interval \\
\hline
\end{tabular}

\footnotetext{
${ }^{7}$ TOECD is growth in trade deficit with OECD
} 


\section{Figure 16}

Fan Chart of IOECD Growth Rate

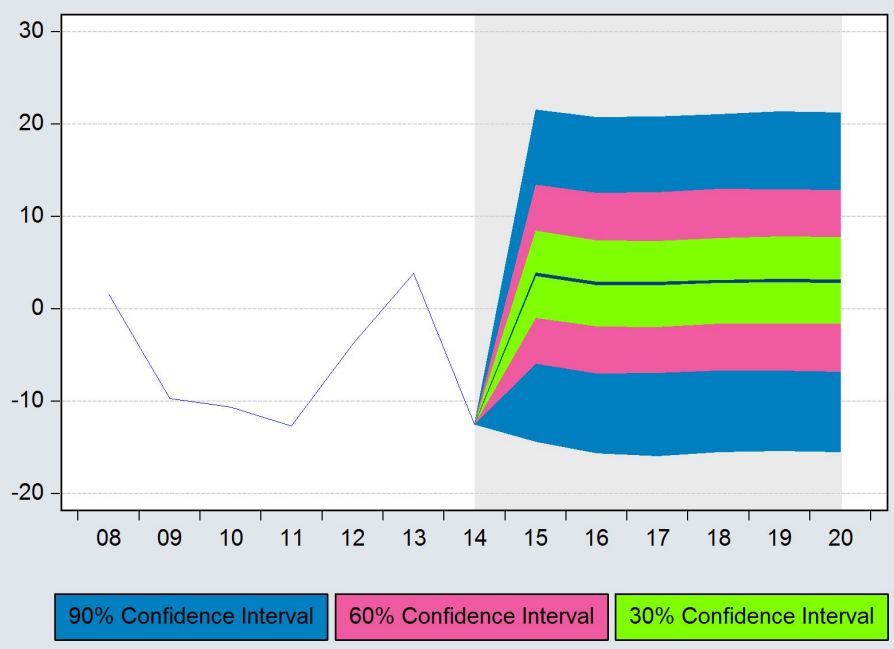

Figure 17

Fan Chart of TOECD Growth Rate

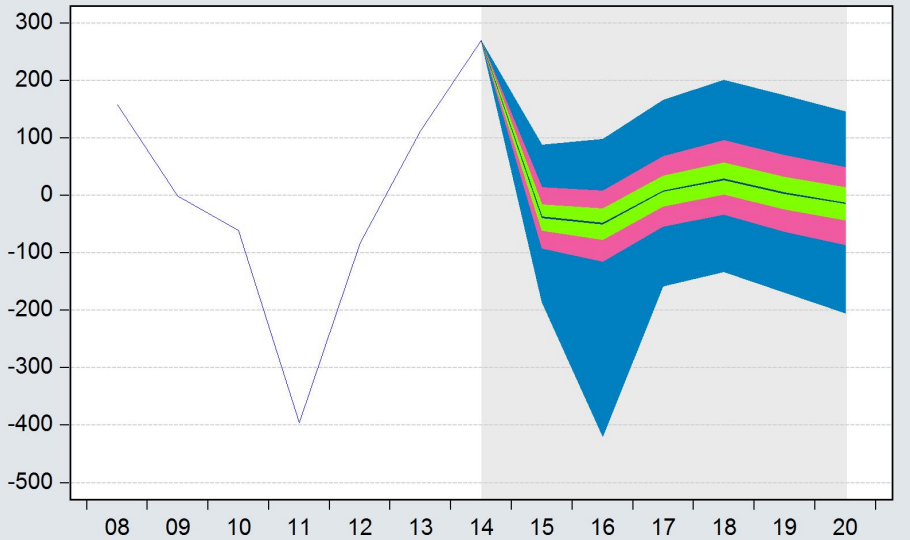

$90 \%$ Confidence Interval $\quad 60 \%$ Confidence Interval $30 \%$ Confidence Interval 
Table 8

Results of Fan Chart of EOECD Growth

\begin{tabular}{|c|c|c|c|c|c|c|c|c|c|c|c|c|}
\hline Year & \multicolumn{2}{|c|}{2015} & \multicolumn{2}{|c|}{2016} & \multicolumn{2}{|c|}{2017} & \multicolumn{2}{|c|}{2018} & \multicolumn{2}{|c|}{2019} & \multicolumn{2}{|c|}{2020} \\
\hline FDI Growth & \multicolumn{2}{|c|}{6.99} & \multicolumn{2}{|c|}{6.357} & \multicolumn{2}{|c|}{6.83} & \multicolumn{2}{|c|}{6.891} & \multicolumn{2}{|c|}{6.908} & \multicolumn{2}{|c|}{6.934} \\
\hline Std. Deviation & \multicolumn{2}{|c|}{12.78} & \multicolumn{2}{|c|}{13.08} & \multicolumn{2}{|c|}{13.08} & \multicolumn{2}{|c|}{13.17} & \multicolumn{2}{|c|}{13.12} & \multicolumn{2}{|c|}{13.27} \\
\hline Skewness & \multicolumn{2}{|c|}{0.601} & \multicolumn{2}{|c|}{0.558} & \multicolumn{2}{|c|}{0.551} & \multicolumn{2}{|c|}{0.552} & \multicolumn{2}{|c|}{0.527} & \multicolumn{2}{|c|}{0.543} \\
\hline Confidence Interval & Lower & Upper & Lower & Upper & Lower & Upper & Lower & Upper & Lower & Upper & Lower & Upper \\
\hline 30 percent & 1.311 & 10.14 & 0.692 & 9.69 & 1.029 & 10.18 & 1.059 & 10.16 & 1.183 & 10.30 & 1.205 & 10.23 \\
\hline 60 percent & -3.444 & 16.10 & -4.238 & 15.80 & -3.768 & 16.23 & -3.737 & 16.38 & -3.687 & 16.51 & -3.745 & 16.37 \\
\hline 90 percent & -10.76 & 31.30 & -12.12 & 31.02 & -11.67 & 31.46 & -11.76 & 31.70 & -11.81 & 31.48 & -11.99 & 31.94 \\
\hline
\end{tabular}

Table 9

Results of Fan Chart of IOECD Growth

\begin{tabular}{|c|c|c|c|c|c|c|c|c|c|c|c|c|}
\hline Year & \multicolumn{2}{|c|}{2015} & \multicolumn{2}{|c|}{2016} & \multicolumn{2}{|c|}{2017} & \multicolumn{2}{|c|}{2018} & \multicolumn{2}{|c|}{2019} & \multicolumn{2}{|c|}{2020} \\
\hline Growth Rate & \multicolumn{2}{|c|}{3.682} & \multicolumn{2}{|c|}{2.686} & \multicolumn{2}{|c|}{2.658} & \multicolumn{2}{|c|}{2.955} & \multicolumn{2}{|c|}{3.065} & \multicolumn{2}{|c|}{2.981} \\
\hline Std. Deviation & \multicolumn{2}{|c|}{11.18} & \multicolumn{2}{|c|}{11.29} & \multicolumn{2}{|c|}{11.36} & \multicolumn{2}{|c|}{11.35} & \multicolumn{2}{|c|}{11.39} & \multicolumn{2}{|c|}{11.39} \\
\hline Skewness & \multicolumn{2}{|c|}{-0.024} & \multicolumn{2}{|c|}{-0.026} & \multicolumn{2}{|c|}{-0.039} & \multicolumn{2}{|c|}{-0.033} & \multicolumn{2}{|c|}{-0.012} & \multicolumn{2}{|c|}{-0.025} \\
\hline Confidence Interval & Lower & Upper & Lower & Upper & Lower & Upper & Lower & Upper & Lower & Upper & Lower & Upper \\
\hline 30 percent & -0.951 & 8.387 & -1.899 & 7.339 & -1.934 & 7.309 & -1.601 & 7.608 & -1.580 & 7.777 & -1.561 & 7.730 \\
\hline 60 percent & -5.951 & 13.39 & -7.007 & 12.51 & -6.921 & 12.55 & -6.695 & 12.93 & -6.680 & 12.90 & -6.789 & 12.81 \\
\hline 90 percent & -14.39 & 21.49 & -15.61 & 20.68 & -15.90 & 20.75 & -15.51 & 21.00 & -15.35 & 21.34 & -15.51 & 21.20 \\
\hline
\end{tabular}

Table 10

Results of Fan Chart of TOECD Growth

\begin{tabular}{|c|c|c|c|c|c|c|c|c|c|c|c|c|}
\hline Year & \multicolumn{2}{|c|}{2015} & \multicolumn{2}{|c|}{2016} & \multicolumn{2}{|c|}{2017} & \multicolumn{2}{|c|}{2018} & \multicolumn{2}{|c|}{2019} & \multicolumn{2}{|c|}{2020} \\
\hline Growth Rate & \multicolumn{2}{|c|}{-41.30} & \multicolumn{2}{|c|}{-78.24} & \multicolumn{2}{|c|}{6.580} & \multicolumn{2}{|c|}{30.54} & \multicolumn{2}{|c|}{3.386} & \multicolumn{2}{|c|}{-19.00} \\
\hline Std. Deviation & \multicolumn{2}{|c|}{79.59} & \multicolumn{2}{|c|}{151.5} & \multicolumn{2}{|c|}{93.60} & \multicolumn{2}{|c|}{96.70} & \multicolumn{2}{|c|}{99.41} & \multicolumn{2}{|c|}{101.6} \\
\hline Skewness & \multicolumn{2}{|c|}{-0.254} & \multicolumn{2}{|c|}{-1.462} & \multicolumn{2}{|c|}{-0.069} & \multicolumn{2}{|c|}{0.088} & \multicolumn{2}{|c|}{-0.026} & \multicolumn{2}{|c|}{-0.279} \\
\hline Confidence Interval & Lower & Upper & Lower & Upper & Lower & Upper & Lower & Upper & Lower & Upper & Lower & Upper \\
\hline 30 percent & -61.28 & -16.06 & -76.81 & -23.19 & -18.61 & 33.66 & 1.667 & 56.36 & -24.28 & 31.67 & -42.87 & 13.61 \\
\hline 60 percent & -92.24 & 14.10 & -115.3 & 8.126 & -54.15 & 68.06 & -33.37 & 96.21 & -62.91 & 70.15 & -85.60 & 49.26 \\
\hline 90 percent & -186.1 & 87.77 & -419.1 & 97.78 & -157.8 & 166.1 & -133.0 & 200.2 & -169.0 & 173.7 & -204.7 & 145.3 \\
\hline
\end{tabular}

\section{Trade with SAARC Countries}

According to Tables 11, 12 and 13 and Figures 18, 19 and 20, the average growth rate of exports to SAARC (ESAARC) from 2015 to 2020 will be 10.26 percent, which is consistent with the findings of Mehmood and Ahmad (2012). Side by side, skewness shows an upside risk in all the forecast 
years. This indicates possible improvement in ESAARC in coming years. In contrast, the average growth in imports from SAARC (ISAARC) will be 15.10 percent from 2015 to 2020. Skewness also shows an upside risk in all the projected years. The average growth in trade balance (deficit) ${ }^{8}$ will remain -71.42 percent from 2015 to 2020. Skewness of all forecast years shows a downside risk except 2020 which indicates that the increase in ESAARC will be higher than increase in ISAARC.

Figure 18

Fan Chart of ESAARC Growth Rate

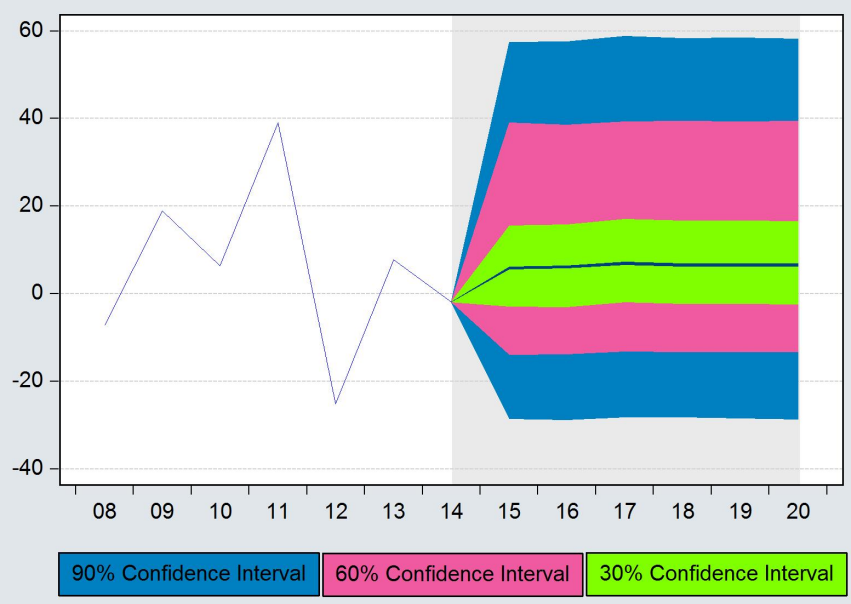

Figure 19

Fan Chart of ISAARC Growth Rate

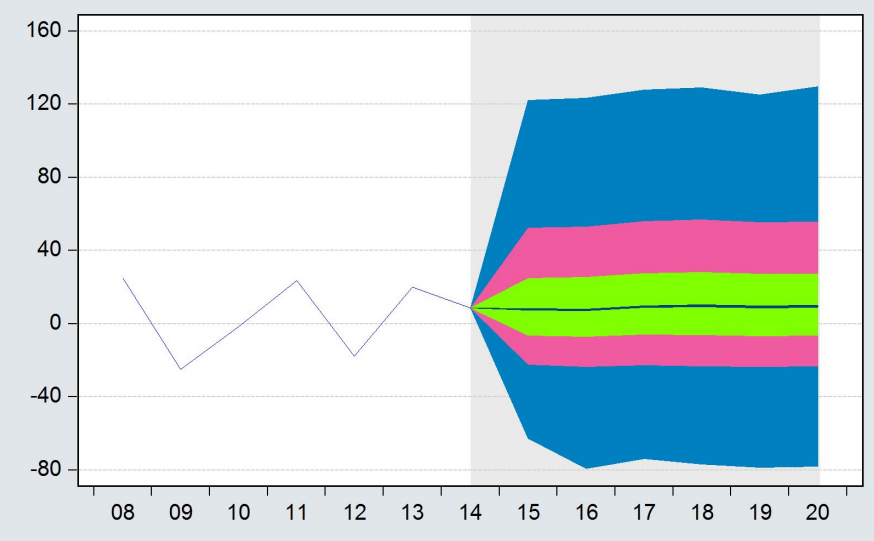

\begin{tabular}{|l|l|l|l}
$90 \%$ Confidence Interval & $60 \%$ Confidence Interval & $30 \%$ Confidence Interval
\end{tabular}

${ }^{8}$ TSAARC is growth in trade deficit with SAARC 


\section{Figure 20}

Fan Chart of TSAARC Growth Rate

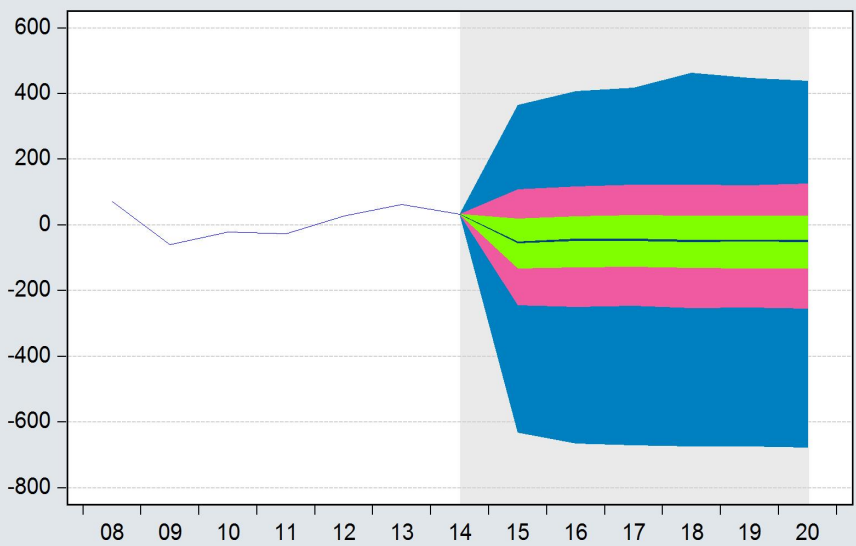

\begin{tabular}{|l|l|l|}
$90 \%$ Confidence Interval & $60 \%$ Confidence Interval & $30 \%$ Confidence Interval \\
\hline
\end{tabular}

Table 11

Results of Fan Chart of ESAARC Growth

\begin{tabular}{|c|c|c|c|c|c|c|c|c|c|c|c|c|}
\hline Year & \multicolumn{2}{|c|}{2015} & \multicolumn{2}{|c|}{2016} & \multicolumn{2}{|c|}{2017} & \multicolumn{2}{|c|}{2018} & \multicolumn{2}{|c|}{2019} & \multicolumn{2}{|c|}{2020} \\
\hline Growth Rate & \multicolumn{2}{|c|}{9.804} & \multicolumn{2}{|c|}{9.804} & \multicolumn{2}{|c|}{10.71} & \multicolumn{2}{|c|}{10.47} & \multicolumn{2}{|c|}{10.45} & \multicolumn{2}{|c|}{10.37} \\
\hline Std. Deviation & \multicolumn{2}{|c|}{27.73} & \multicolumn{2}{|c|}{27.72} & \multicolumn{2}{|c|}{27.87} & \multicolumn{2}{|c|}{27.81} & \multicolumn{2}{|c|}{27.87} & \multicolumn{2}{|c|}{27.88} \\
\hline Skewness & \multicolumn{2}{|c|}{0.497} & \multicolumn{2}{|c|}{0.428} & \multicolumn{2}{|c|}{0.424} & \multicolumn{2}{|c|}{0.429} & \multicolumn{2}{|c|}{0.427} & \multicolumn{2}{|c|}{0.418} \\
\hline Confidence Interval & Lower & Upper & Lower & Upper & Lower & Upper & Lower & Upper & Lower & Upper & Lower & Upper \\
\hline 30 percent & -2.913 & 15.54 & -2.960 & 15.77 & -1.925 & 16.98 & -2.278 & 16.68 & -2.230 & 16.66 & -2.429 & 16.55 \\
\hline 60 percent & -13.88 & 39.09 & -13.79 & 38.49 & -13.11 & 39.34 & -13.23 & 39.38 & -13.22 & 39.30 & -13.26 & 39.43 \\
\hline 90 percent & -28.59 & 57.41 & -28.83 & 57.56 & -28.19 & 58.76 & -28.20 & 58.32 & -28.42 & 58.46 & -28.61 & 58.18 \\
\hline
\end{tabular}

Source: Authors' Estimation

Table 12

Results of Fan Chart of ISAARC Growth

\begin{tabular}{|c|c|c|c|c|c|c|c|c|c|c|c|c|}
\hline Year & \multicolumn{2}{|c|}{2015} & \multicolumn{2}{|c|}{2016} & \multicolumn{2}{|c|}{2017} & \multicolumn{2}{|c|}{2018} & \multicolumn{2}{|c|}{2019} & \multicolumn{2}{|c|}{2020} \\
\hline Growth Rate & \multicolumn{2}{|c|}{15.35} & \multicolumn{2}{|c|}{13.36} & \multicolumn{2}{|c|}{15.97} & \multicolumn{2}{|c|}{15.87} & \multicolumn{2}{|c|}{14.61} & \multicolumn{2}{|c|}{15.417} \\
\hline Std. Deviation & \multicolumn{2}{|c|}{54.67} & \multicolumn{2}{|c|}{58.76} & \multicolumn{2}{|c|}{59.04} & \multicolumn{2}{|c|}{60.12} & \multicolumn{2}{|c|}{59.34} & \multicolumn{2}{|c|}{60.49} \\
\hline Skewness & \multicolumn{2}{|c|}{0.672} & \multicolumn{2}{|c|}{0.403} & \multicolumn{2}{|c|}{0.498} & \multicolumn{2}{|c|}{0.461} & \multicolumn{2}{|c|}{0.396} & \multicolumn{2}{|c|}{0.460} \\
\hline Confidence Interval & Lower & Upper & Lower & Upper & Lower & Upper & Lower & Upper & Lower & Upper & Lower & Upper \\
\hline 30 percent & -6.510 & 24.77 & -6.997 & 25.45 & -5.799 & 27.55 & -6.052 & 28.01 & -6.623 & 27.21 & -6.421 & 27.22 \\
\hline 60 percent & -22.17 & 52.21 & -23.49 & 53.00 & -22.58 & 55.99 & -23.24 & 56.66 & -23.57 & 55.25 & -23.29 & 55.60 \\
\hline 90 percent & -62.84 & 121.9 & -79.15 & 123.1 & -73.98 & 127.9 & -76.74 & 129.1 & -78.50 & 125.0 & -78.19 & 129.6 \\
\hline
\end{tabular}

Source: Authors' Estimation 
Table 13

Results of Fan Chart of TSAARC Growth

\begin{tabular}{|c|c|c|c|c|c|c|c|c|c|c|c|c|}
\hline Year & \multicolumn{2}{|c|}{2015} & \multicolumn{2}{|c|}{2016} & \multicolumn{2}{|c|}{2017} & \multicolumn{2}{|c|}{2018} & \multicolumn{2}{|c|}{2019} & \multicolumn{2}{|c|}{2020} \\
\hline Growth Rate & \multicolumn{2}{|c|}{-77.72} & \multicolumn{2}{|c|}{-72.63} & \multicolumn{2}{|c|}{-70.41} & \multicolumn{2}{|c|}{-67.57} & \multicolumn{2}{|c|}{-69.42} & \multicolumn{2}{|c|}{-70.79} \\
\hline Std. Deviation & \multicolumn{2}{|c|}{287.3} & \multicolumn{2}{|c|}{307.4} & \multicolumn{2}{|c|}{311.5} & \multicolumn{2}{|c|}{323.4} & \multicolumn{2}{|c|}{319.4} & \multicolumn{2}{|c|}{319.1} \\
\hline Skewness & \multicolumn{2}{|c|}{-0.521} & \multicolumn{2}{|c|}{-0.498} & \multicolumn{2}{|c|}{-0.490} & \multicolumn{2}{|c|}{-0.326} & \multicolumn{2}{|c|}{-0.380} & \multicolumn{2}{|c|}{0.414} \\
\hline Confidence Interval & Lower & Upper & Lower & Upper & Lower & Upper & Lower & Upper & Lower & Upper & Lower & Upper \\
\hline 30 percent & -131.4 & 18.56 & -127.1 & 26.11 & -126.4 & 30.04 & -130.4 & 27.3 & -131.4 & 27.91 & -132.2 & 28.05 \\
\hline 60 percent & -243.4 & 107.8 & -249.1 & 117.5 & -245.8 & 121.9 & -251.3 & 121.9 & -250.5 & 120.6 & -253.4 & 125.2 \\
\hline 90 percent & -631.7 & 364.5 & -664.5 & 406.9 & -670.1 & 417.1 & -673.8 & 462.8 & -673.4 & 446.6 & -676.7 & 438.5 \\
\hline
\end{tabular}

\section{Trade with ASEAN Countries}

Tables 14, 15 and 16 and Figures 21, 22 and 23 show that the average growth rate of exports to ASEAN (EASEAN) countries from 2015 to 2020 is 9.78 percent. Side by side, skewness shows an upside risk in all the forecast years. This indicates chances of improvement in EASEAN in coming years. In contrast, average growth in import from ASEAN (IASEAN) will be -23.04 percent from 2015 to 2020. Skewness shows an upside risk in 2015, 2016, 2017 and 2020 and a downside risk in 2018 and 2019. The average growth in trade balance (deficit) ${ }^{9}$ will be 2.75 percent from 2015 to 2020. Skewness of all forecast years shows downside risk in all forecast years.

\section{Figure 21}

Fan Chart of EASEAN Growth Rate

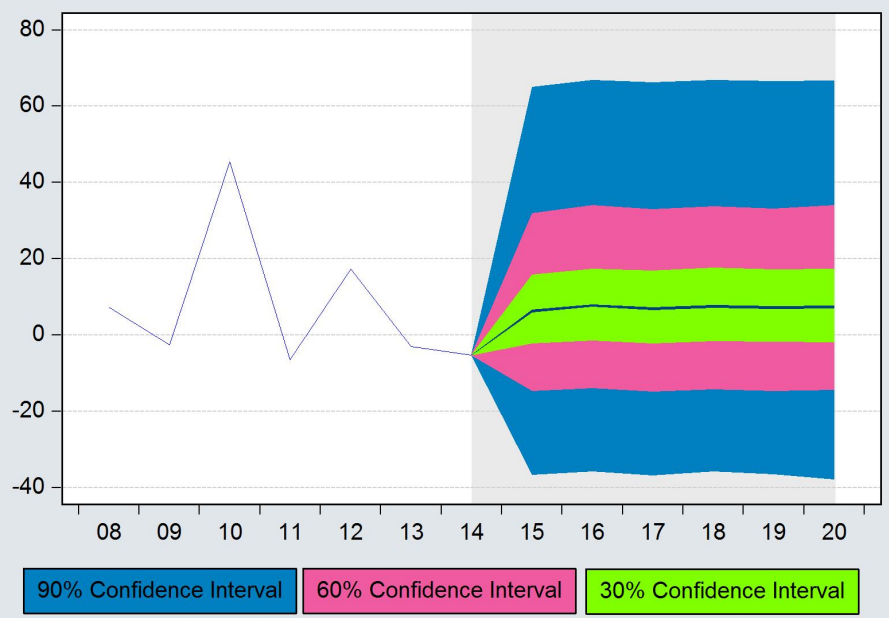

\footnotetext{
${ }^{9}$ TASEAN is growth in trade deficit with ASEAN
} 


\section{Figure 22}

Fan Chart of IASEAN Growth Rate

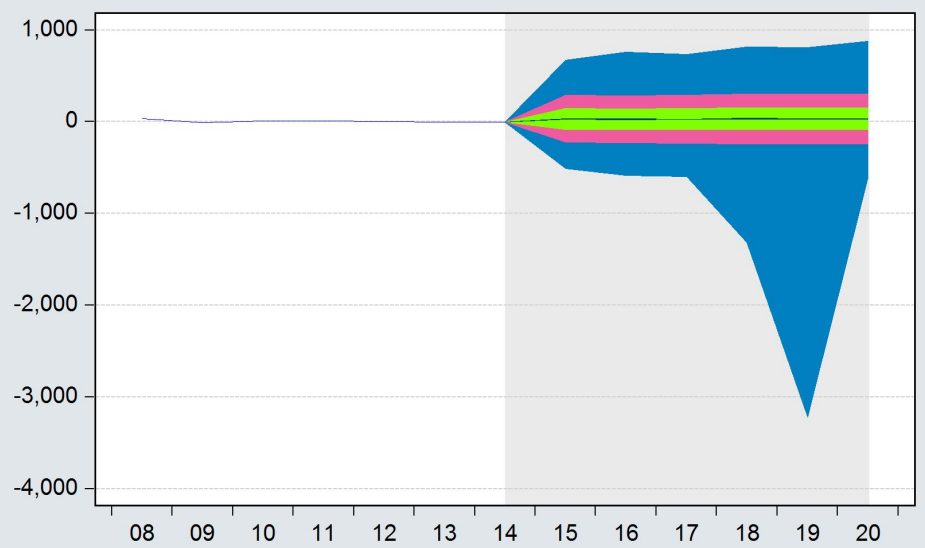

\begin{tabular}{|l|l|l|}
\hline $90 \%$ Confidence Interval & $60 \%$ Confidence Interval & $30 \%$ Confidence Interval \\
\hline
\end{tabular}

\section{Figure 23}

Fan Chart of TASEAN Growth Rate

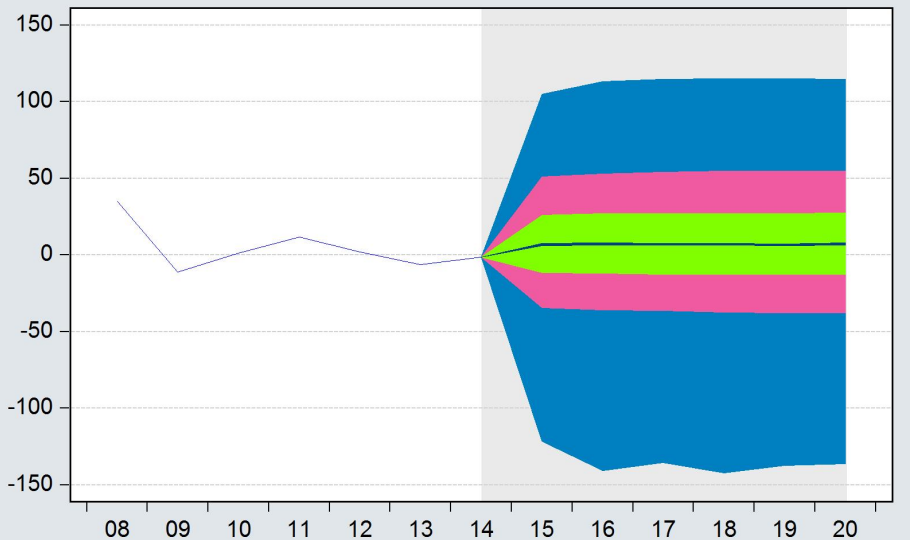

\begin{tabular}{|l|l|l|}
$90 \%$ Confidence Interval & $60 \%$ Confidence Interval & $30 \%$ Confidence Interval \\
\hline
\end{tabular} 
Table 14

Results of Fan Chart of EASEAN Growth

\begin{tabular}{|c|c|c|c|c|c|c|c|c|c|c|c|c|}
\hline Year & \multicolumn{2}{|c|}{2015} & \multicolumn{2}{|c|}{2016} & \multicolumn{2}{|c|}{2017} & \multicolumn{2}{|c|}{2018} & \multicolumn{2}{|c|}{2019} & \multicolumn{2}{|c|}{2020} \\
\hline Growth Rate & \multicolumn{2}{|c|}{9.000} & \multicolumn{2}{|c|}{10.31} & \multicolumn{2}{|c|}{9.507} & \multicolumn{2}{|c|}{10.20} & \multicolumn{2}{|c|}{9.831} & \multicolumn{2}{|c|}{9.857} \\
\hline Std. Deviation & \multicolumn{2}{|c|}{30.47} & \multicolumn{2}{|c|}{30.85} & \multicolumn{2}{|c|}{30.93} & \multicolumn{2}{|c|}{30.89} & \multicolumn{2}{|c|}{30.94} & \multicolumn{2}{|c|}{31.34} \\
\hline Skewness & \multicolumn{2}{|c|}{0.425} & \multicolumn{2}{|c|}{0.420} & \multicolumn{2}{|c|}{0.411} & \multicolumn{2}{|c|}{0.423} & \multicolumn{2}{|c|}{0.415} & \multicolumn{2}{|c|}{0.368} \\
\hline Confidence Interval & Lower & Upper & Lower & Upper & Lower & Upper & Lower & Upper & Lower & Upper & Lower & Upper \\
\hline 30 percent & -2.206 & 15.82 & -1.415 & 17.22 & -2.075 & 16.78 & -1.516 & 17.59 & -1.691 & 17.164 & -1.825 & 17.34 \\
\hline 60 percent & -14.58 & 31.91 & -13.91 & 34.04 & -14.76 & 32.97 & -14.23 & 33.67 & -14.57 & 33.16 & -14.34 & 33.97 \\
\hline 90 percent & -36.68 & 65.07 & -35.72 & 66.82 & -36.83 & 66.15 & -35.77 & 66.86 & -36.46 & 66.58 & -37.80 & 66.73 \\
\hline
\end{tabular}

Source: Authors' Estimation

Table 15

Results of Fan Chart of IASEAN Growth

\begin{tabular}{|c|c|c|c|c|c|c|c|c|c|c|c|c|}
\hline Year & \multicolumn{2}{|c|}{2015} & \multicolumn{2}{|c|}{2016} & \multicolumn{2}{|c|}{2017} & \multicolumn{2}{|c|}{2018} & \multicolumn{2}{|c|}{2019} & \multicolumn{2}{|c|}{2020} \\
\hline Growth Rate & \multicolumn{2}{|c|}{42.79} & \multicolumn{2}{|c|}{41.01} & \multicolumn{2}{|c|}{37.23} & \multicolumn{2}{|c|}{-38.26} & \multicolumn{2}{|c|}{-277.9} & \multicolumn{2}{|c|}{56.89} \\
\hline Std. Deviation & \multicolumn{2}{|c|}{349.8} & \multicolumn{2}{|c|}{390.3} & \multicolumn{2}{|c|}{388.0} & \multicolumn{2}{|c|}{605.8} & \multicolumn{2}{|c|}{1229} & \multicolumn{2}{|c|}{432.9} \\
\hline Skewness & \multicolumn{2}{|c|}{0.266} & \multicolumn{2}{|c|}{0.289} & \multicolumn{2}{|c|}{0.204} & \multicolumn{2}{|c|}{-0.981} & \multicolumn{2}{|c|}{-1.959} & \multicolumn{2}{|c|}{0.446} \\
\hline Confidence Interval & Lower & Upper & Lower & Upper & Lower & Upper & Lower & Upper & Lower & Upper & Lower & Upper \\
\hline 30 percent & -84.83 & 143.9 & -86.34 & 139.3 & -88.80 & 143.9 & -86.54 & 153.6 & -87.29 & 152.4 & -87.45 & 151.5 \\
\hline 60 percent & -222.2 & 286.6 & -232.4 & 282.7 & -234.2 & 287.4 & -240.0 & 302.9 & -239.3 & 301.9 & -239.4 & 303.7 \\
\hline 90 percent & -509.3 & 671.3 & -586.7 & 757.2 & -598.0 & 734.9 & -1316 & 815.1 & -3220 & 807.0 & -617.7 & 879.9 \\
\hline
\end{tabular}

Source: Authors' Estimation

Table 16

Results of Fan Chart of TASEAN Growth

\begin{tabular}{|c|c|c|c|c|c|c|c|c|c|c|c|c|}
\hline Year & \multicolumn{2}{|c|}{2015} & \multicolumn{2}{|c|}{2016} & \multicolumn{2}{|c|}{2017} & \multicolumn{2}{|c|}{2018} & \multicolumn{2}{|c|}{2019} & \multicolumn{2}{|c|}{2020} \\
\hline Growth Rate & \multicolumn{2}{|c|}{3.416} & \multicolumn{2}{|c|}{2.303} & \multicolumn{2}{|c|}{3.022} & \multicolumn{2}{|c|}{2.178} & \multicolumn{2}{|c|}{2.645} & \multicolumn{2}{|c|}{2.982} \\
\hline Std. Deviation & \multicolumn{2}{|c|}{65.91} & \multicolumn{2}{|c|}{73.34} & \multicolumn{2}{|c|}{72.39} & \multicolumn{2}{|c|}{74.48} & \multicolumn{2}{|c|}{73.16} & \multicolumn{2}{|c|}{72.80} \\
\hline Skewness & \multicolumn{2}{|c|}{-0.459} & \multicolumn{2}{|c|}{-0.577} & \multicolumn{2}{|c|}{-0.480} & \multicolumn{2}{|c|}{-0.550} & \multicolumn{2}{|c|}{-0.485} & \multicolumn{2}{|c|}{-0.484} \\
\hline Confidence Interval & Lower & Upper & Lower & Upper & Lower & Upper & Lower & Upper & Lower & Upper & Lower & Upper \\
\hline 30 percent & -11.59 & 26.02 & -11.95 & 26.85 & -12.71 & 26.83 & -12.86 & 26.84 & -12.83 & 26.86 & -12.82 & 27.29 \\
\hline 60 percent & -34.49 & 51.04 & -35.88 & 52.96 & -36.46 & 53.82 & -37.46 & 54.56 & -37.94 & 54.55 & -37.79 & 54.69 \\
\hline 90 percent & -121.8 & 104.7 & -140.9 & 113.0 & -135.6 & 114.6 & -142.3 & 115.0 & -137.4 & 115.0 & -136.2 & 114.7 \\
\hline
\end{tabular}

\section{Concluding Remarks}

This study analyzes and forecasts the overall and regional trade of Pakistan. The considered region are OIC, OECD, SAARC and ASEAN which cover almost $80 \%$ of total trade of Pakistan. This study is a pioneering attempt to forecast aggregate and regional trade from 2015 to 2020 with fan 
chart approach by using annual data from 1974 to 2014. This approach of forecast not only makes predictions for a particular point in future but also identifies the uncertainty associated with the forecast. This approach also provides risk information in the context of upside and downside risk.

The results reveal that in case of overall trade, the risk associated with export is predicted to be downside during all the forecast years, except 2018. Imports and trade deficit have an upside risk in all the forecast years. Trade with OIC has an upside risk in export, import, and trade deficit. Trade with OECD shows favorable conditions for Pakistan in near future, whereas, exports with OECD indicate upside risk and import and trade deficit shows downside risk. Trade deficit with OECD has upside risk in 2018 only. Trade condition with SAARC countries will be better in forecasted years. Growth in export and import with SAARC have upside risk in all forecasted years while, trade deficit with SAARC has a downside risk. In the case of ASEAN, exports and growth are positive and have an upside in coming years. On the other hand, imports with positive growth having upside risk in 2015, 2016, 2017 and 2020 and downside risk in 2018 and 2019. As far as the trade deficit is concerned, it has a trade deficit having downside risk in all the projected years. The results also suggest that there is considerable uncertainty associated with these forecasts. The policy makers are recommended to monitor the downside risk associated with exports and the upside risk associated with imports of the country.

Policy makers are also suggested to attract and retain both private and foreign direct investment in Pakistan, which can be used to sustain export growth mostly with upside risk in the country. Side by side, import growth has been observed to have an upside risk, except import growth from OECD countries which has a downside risk. If one accepts Jawaid (2014)'s findings of positive effect of aggregate export on economic growth and negative effect of aggregate imports on economic growth, import growth should be analyzed regionally as well as through commodity wise import contents. Those contents which substitute efficient domestic production should not be encouraged.

The above risk and uncertainty analysis suggests us to conduct for further research by analyzing trade of commodity groups, with these regions to make more growth friendly policies. This analysis will also help us to identify those regions which are more beneficial in terms of export, import and trade balance for Pakistan. 


\section{References}

Ahmad, B., \& Mustafa, K. (2006). Forecasting kinnow production in Pakistan: An econometrics analysis. International Journal of Agriculture 83 Biology, 8(4), 455458.

Akram, Q. F., Binning, A., \& Maih, J. (2016). Joint prediction bands for macroeconomic risk management. CAMP Working Paper Series No 5/2016.

Blix, M., \& Sellin, P. (1998). Uncertainty bands for inflation forecasts. Sveriges Riksbank Working Paper No 65.

Camilleri, G., \& Vella, K. (2015). Interpolating forecast errors for assessing uncertainty in macroeconomic forecasts: An analysis for Malta. Ministry of Finance, Economic Policy Department Working Paper Series WP 01/2015..

Carbaugh, R. J. (2004). International economics. Thomson South-Western, Australia.

Castillo, M. A. (2016). Template for external sustainability assessment (Tech. Rep.). Inter-American Development Bank Techical Note IDB-TN-1095.

De Luna, X. (2000). Prediction intervals based on autoregression forecasts. Journal of the Royal Statistical Society: Series D (The Statistician), 49(1), 87-93.

Din, M. U., Ghani, E., \& Siddique, O. (2003). Openness and economic growth in Pakistan. The Pakistan Development Review, 42(4), 795-807.

Dowd, K., Blake, D., \& Cairns, A. J. (2016). The myth of methuselah and the uncertainty of death: The mortality fan charts. Risks, 4(3), 1-7.

Farooqi, A. (2014). ARIMA model building and forecasting on imports and exports of Pakistan. Pakistan Journal of Statistics and Operation Research, 10(2), 157-168.

Fukač, M., \& Kirkby, R. (2017). Accounting for uncertainty in public debt targets. Australian Economic Review, 50(1), 89-102.

Fuller, W. A., \& Hasza, D. P. (1981). Properties of predictors for autoregressive time series. Journal of the American Statistical Association, 76(373), 155-161.

Ghafoor, A., \& Hanif, S. (2005). Analysis of the trade pattern of Pakistan: Past trends and future prospects. Journal of Agriculture \& Social Sciences, 1(4), 346-349.

Gul, N., \& Yasin, H. M. (2011). The trade potential of Pakistan: an application of the gravity model. The Lahore Journal of Economics, 16(1), 23-62.

Hye, Q. M. A. (2012). Long term effect of trade openness on economic growth in case of Pakistan. Quality \& Quantity, 46(4), 1137-1149.

Iqbal, N., Bakhsh, K., Maqbool, A., \& Ahmad, A. S. (2005). Use of the ARIMA model for forecasting wheat area and production in Pakistan. Journal of Agriculture and Social Sciences, 1(2), 120-122.

Jawaid, S. T. (2014). Trade openness and economic growth: A lesson from Pakistan. Foreign Trade Review, 49(2), 193-212.

Kannan, P., \& Elekdag, S. (2009). Incorporating market information into the construction of the fan chart(no. 9-178). IMF Working Paper, WP/09/178.

Khan, M., Mustafa, K., Shah, M., Khan, N., \& Khan, J. Z. (2008). Forecasting mango production in Pakistan an econometric model approach. Sarhad J. Agric, 24(2), 363-370. 
Mehmood, S., \& Ahmad, Z. (2012). Forecasting Pakistan's exports to SAARC: An application of univiriate ARIMA model. Journal of Contemporary Issues in Business Research, 1(3), 41-54.

Muhammad, S. D. (2010). The effectiveness of financial development and openness on economic growth: Case study of Pakistan. European Journal of Social Sciences, $13(3), 415-425$.

Naz, F. (2013). A univariate time series modelling of dates exports in Pakistan. Journal of Contemporary Issues in Business Research, 1(2), 37-48.

Raza, S. A., \& Karim, M. Z. A. (2017). Influence of systemic banking crisis \& currency crisis on the relationship of export \& economic growth: Evidence from China. Journal of Chinese Economic and Foreign Trade Studies, 10(1), 82-110.

Shahbaz, M. (2012). Does trade openness affect long run growth? cointegration, causality and forecast error variance decomposition tests for Pakistan. Economic Modelling, $29(6), 2325-2339$.

Ullah, S., Zaman, B., Farooq, M., \& Javid, A. (2009). Cointegration and causality between exports and economic growth in Pakistan. European Journal of Social Sciences, $10(2), 264-272$.

$\mathrm{Yu}, \mathrm{H}$. (2011). Uncertainty and risk analysis of the langrun chinese GDP forecast: Fan charts revisited. China Economic Journal, 4 (2-3), 81-104.

Zaidi, S. A. (2005). Issues in Pakistan's economy. Oxford University Press, United Kingdom.

Zaman, K. (2010). Trade liberalization, financial development and economic growth: Evidence from Pakistan (1980-2009). Journal of International Academic Research, 10(2), 30-37. 